\title{
Warlpiri and the theory of second position clitics
}

\author{
Julie Anne Legate
}

Received: 3 February 2005 / Accepted: 28 June 2007 /

Published online: 16 January 2008

(C) Springer Science + Business Media B.V. 2007

\begin{abstract}
This paper examines the placement of aspect and agreement clitics in Warlpiri. A common misconception regarding clitic placement in Warlpiri is cleared up: clitic placement does not depend on syllable count. It is also shown that these clitics do not uniformly appear in second position, syntactically or phonologically, making the standard label of "second position clitics" a misnomer. An analysis is developed in terms of syntactic head movement combined with local morphological reordering. The discussion also reveals a genuine morphological first word phenomenon, whereby a preverb may be split from its associated verb.
\end{abstract}

Keywords Second position clitics $\cdot$ Clitics $\cdot$ Preverb $\cdot$ Warlpiri

\section{Introduction}

In the literature, there are two standard assumptions about Warlpiri tense/ aspect/agreement clitics: (i) they are second position clitics; and (ii) their placement is regulated by a phonological requirement of disyllabicity. (For relevant literature, see for example Anderson 1993, 1996, 2000, 2005; Billings 2002; Embick and Noyer 1999; Hale 1973, 1983; Halpern 1995; Laughren 1989; Nash 1986; Simpson 1991 an important exception is Laughren 2002, on which this paper builds.) In this paper, I argue that neither of these assumptions is true. On the broadest stroke, I demonstrate that the Warlpiri clitics are best described as complementizer clitics (see McConvell 1996, for a related analysis of the Ngumpin Pama-Nyungan language Gurindji). While I show that

J. A. Legate $(\varangle)$

Department of Linguistics, Cornell University, 217 Morrill Hall, Ithaca, NY 14853, USA

e-mail: jal252@cornell.edu 
the notions of "second" or "initial" have no relevance to the positioning of Warlpiri "second position clitics", I leave open whether or not these notions have any relevance to the positioning of a class of clitics crosslinguistically.

In Section 2, I reexamine the assumed importance of phonology in the placement of Warlpiri clitics. This assumption originates from a generalization stated in Hale (1973): disyllabic clitics may appear initially, monosyllabic ones may not. However, as I discuss in Section 2.1, Hale's generalization is based on an early misanalysis of a Warlpiri morpheme. Although the error is corrected in later work, the consequences for clitics escaped notice. And the consequences are significant: the correct generalization turns out to be one based on part of speech rather than phonological weight, thus eliminating the crucial evidence for phonological placement.

In Section 2.2, I reexamine another oft-cited phonological generalization regarding Warlpiri clitics: that they may appear initially when cliticized to a preceding clause. I demonstrate that although there is no evidence for cliticization to a preceding clause, there is phonological and phonetic evidence suggesting that the clitic in the relevant clitic-initial examples is currently in flux, behaving sometimes as a clitic and other times as an independent phonological word.

The remainder of the paper develops an analysis of clitic placement in Warlpiri. Section 3 begins by arguing, on theoretical and empirical grounds, that the placement of Warlpiri clitics must be primarily accomplished through syntactic head movement. Any additional operations will then require compelling motivation. Section 3.1 considers an analysis (Austin and Bresnan 1996) based on a unique syntactic position for the clitics, plus a phonological operation, Prosodic Inversion (Halpern 1995); although attractive in its simplicity, this analysis is shown to be inadequate. Warlpiri clitics do not occupy a single syntactic position. Furthermore, it is shown that any needed operation in addition to syntactic head movement cannot be phonological in nature. Section 3.2 considers applying to Walpiri Boškovićs (2001) analysis of Serbo-Croatian clitic placement. This analysis combines optional syntactic movement, a lexical requirement on the prosodic position of the clitics, and pronunciation of lower copies in the chain formed by syntactic clitic movement. I show that this analysis cannot be applied to Warlpiri. Warlpiri clitics do not appear in a unique prosodic position; furthermore, they may appear in a position that they cannot occupy in the syntax: between a preverb and its verb.

Section 4 proposes a morphosyntactic analysis of clitic placement in Warlpiri. Section 4.1 details the primary syntactic component: head-movement based on Attract, which places the clitics in a high functional head; the identity of this head is dependent on the functional projections present in the clause. In the simplest case, this movement, combined with simple linearization mechanisms is all that is required. Section 4.2 provides an analysis for the construction in which the clitics may appear in a position they cannot occupy in the syntax. A morphological operation is proposed, one that is shown to be independently required for affixation, and limited in application to the $\mathrm{X}^{0}$ domain. 


\section{Phonological generalizations}

\subsection{The Disyllabic generalization}

Warlpiri displays a clitic cluster, formed of an aspectual clitic, typically referred to as an "auxiliary", and subject agreement and object agreement clitics, usually in that order (see Hale 1973, and footnote 34 for discussion of limited deviations from this order) $:^{1}$
(1) Maliki-jarra-rlu-ka-pala-jana puluku-patu wajilipi-nyi dog-Dual-Erg-PresImpf-3DualSubj-3plObj bullock-Pauc chase-Npast The two dogs are chasing the several bullocks.

These are enclitics, attaching unselectively to the preceding prosodic word. This phonological dependence is illustrated for example by the application of $u / i$ vowel harmony to the sequence of suffixes and clitics, as illustrated in (2) (see Nash 1986; Harvey and Baker 2005, for discussion of vowel harmony in Warlpiri)). (2a) shows the underlying form of the suffixes and clitics (the noun minija 'cat' ends in $a$, which is inert for vowel harmony), and (2b) shows application of the harmony throughout the suffixes and clitics (the noun maliki 'dog' ends in $i$, which triggers progressive harmony). ${ }^{2}$

(2) a. minija-kurlu-rlu-lku-ju-lu

$$
\text { cat-Prop-Erg-now-1 } \overline{s g O b} \text {-3plSubj }
$$

b. maliki-kirli-rli-lki-ji-li

dog-Prop-Erg-now-1sgObj-3plSubj

(Nash 1986)

In contrast, vowel harmony does not apply between prosodic words, for example within nominal compounds, or between preverbs and verbs:
a. miyi kupu-rnu
food winnow-Nomin
food winnower
b. pirri-kuju-rnu
scattered-throw-Past
scattered (Nash 1986)

Our interest here is the placement of these clitics. An often-cited generalization for clitic placement in Warlpiri is as follows: when the auxiliary consists of one syllable or where it is phonologically null, the clitics must appear in

\footnotetext{
${ }^{1}$ An anonymous reviewer asks if the clitic cluster in Warlpiri can be split, as in Serbo-Croatian (Stjepanović 1998; Bošković 2001). No such examples are attested, however the issue has not been investigated experimentally.

${ }^{2}$ Nash gives the translation 'As for the cats, they are with me now' for (2a) and 'As for the dogs, they are with me now' for (2b). As an anonymous reviewer notes, these are not really appropriate in that the examples involve fragments rather than complete clauses.
} 
second position; when the auxiliary consists of two or more syllables, the clitics may appear either initially or in second position. This generalization has led many researchers to conclude that Warlpiri clitic placement is phonological in nature (see for example Anderson 2000; Billings 2002; Embick and Noyer 1999;3 Hale 1973; Laughren 1989; Nash 1986; Simpson 1991). And indeed, the generalization has seemed very natural given that the prosodic word in Warlpiri is minimally disyllabic (Nash 1986), ${ }^{4}$ a fact which has played important roles in some analyses Anderson (2000), Billings (2002).

The apparent naturalness of the generalization is partially eroded by the fact that while the auxiliary and agreement markers are all clitics, only the auxiliary (and the non-clitic complementizers) apply to the syllable count. Thus, for the clitic cluster in (4), it is claimed that although it consists of six syllables, it cannot appear initially because only one of the syllables comes from an auxiliary clitic, $k a$, while the remaining five syllables are from agreement clitics. Why the phonology would make such a distinction has not been explained on any account.

(4) ka-nkulu-jarrangku

PresImpf-2plSubj-1DualExclObj

you (plural) acting on us (dual exclusive)

Natural or not, the generalization has become common lore to such an extent that it is often cited without data and without source. The source is Hale (1973:312-3). Hale proposes that the clitics are generated initially; subsequently an Aux-Insertion rule applies to place them after the first constituent, where application of the rule is dependent on syllable count (I leave aside the issue of negation until Section 3):

I will assume that the auxiliary is basically initial in Walbiri and that it is moved into second position by the Aux-Insertion Rule. Furthermore, Aux-Insertion is $(a)$ obligatory if the portion of the auxiliary preceding the person markers is less than disyllabic (that is monosyllabic or phonologically null), (b) blocked if the auxiliary is negative and is immediately followed by the verb, and $(c)$ optional otherwise. This insertion must be ordered in the grammar to follow all syntactic operations which have an effect on the ordering of nonauxiliary constituents. Hale (1973:313)

The contrast Hale uses to motivate his generalization is the following:
a. Wawiri-ka-rna purra-mi. kangaroo-PresImpf-1sgSubj cook-Npast
I am cooking the kangaroo.

\footnotetext{
${ }^{3}$ Embick and Noyer (1999) discussion of Warlpiri is brief, and based on the mistaken belief that the entire clitic cluster counts towards the syllable count (see immediately below). We do not consider their analysis further.

${ }^{4}$ More accurately, bimoraic. 


\section{b. Kapi-rna wawiri purra-mi. Future-1sgSubj kangaroo cook-Npast \\ I will cook the kangaroo.}

He states that both $k a$ and kapi here are auxiliaries; the relevant distinction between them is that $k a$ is monosyllabic, whereas kapi is disyllabic.

This paper represents a relatively early period in Hale's work on Warlpiri (1973). This means that I have had to update the examples to the now standard orthography. It also means that kapi in (5b) is misanalysed. In Hale's own later work, and in that of his colleagues, it is recognized that the future kapi is not an auxiliary but rather a complementizer (see for example Simpson 1991; Hale et al. 1995; Laughren 2002). The auxiliaries and complementizers in Warlpiri are listed below. ${ }^{5}$

\begin{tabular}{|ll|ll|}
\hline Complementizers & & Auxiliaries & \\
\hline kuja & 'that' & ka & Present Imperfective \\
kaji & 'if/when' & lpa & Past Imperfective \\
yinga & 'for, since' & $\varnothing$ & Perfective \\
yi & 'for, since' & & \\
yungu & 'for, since' & & \\
kala & remote past & & \\
kala & potential & & \\
kapi & future & & \\
\hline
\end{tabular}

The probable cause of the initial mis-characterization of kapi is that kapi appears to be in complementary distribution not only with other complementizers, but also with the auxiliaries. For example, the cooccurrence of kapi and the declarative complementizer kuja is ungrammatical (in either ordering), but so is the cooccurrence of kapi and the imperfective aspect auxiliaries$k a$ present imperfective and lpa past imperfective. ${ }^{6}$ The complementarity of $k a p i$ with the aspectual auxiliaries, however, turns out to have an independent source. The future is incompatible with (imperfective) aspect within the same clause, regardless of morphological realization. This is clearly shown in western dialects of Warlpiri. In these dialects, the future is marked as a verbal suffix. Although aspect marking freely cooccurs with other verbal suffixes in both dialects, aspect marking cannot cooccur with the future suffix: ${ }^{7}$

(7) Ngaka-(*lpa/*ka)-rna-ngku nya-ngku.

later-PastImpf/PresImpf-1sgSubj-2sgObj see-Fut

I'll see you later./I'll be seeing you later.

Thus, morphological realization of both future and imperfective aspect marking are incompatible in Warlpiri, regardless of the manner in which the future

\footnotetext{
${ }^{5} \mathrm{~A}$ few additional possible complementizers have been left out because their status is unclear; these are all disyllabic, however, and thus not ultimately relevant for the present discussion.

${ }^{6}$ The perfective aspect cannot be tested since it is phonologically null.

${ }^{7}$ Aspect marking is also incompatible with the imperative verbal suffix in all dialects.
} 
is realized. The source of this restriction deserves investigation; however, for current purposes the essential point is that the apparent complementary distribution between kapi and the aspectual auxiliaries has an independent source. The complementary distribution between kapi and other complementizers, on the other hand, does not have an independent source, and is best explained by kapi belonging to the series of complementizers. ${ }^{8}$

Returning to the contrast in (5), we now have two possible explanations. The first is the analysis of Hale (1973) based on number of syllables preceding the agreement clitics: if two or more syllables precede the agreement clitics, initial placement is possible; if one or fewer syllables precede the agreement clitics, initial placement is impossible. ${ }^{9}$ The second is an analysis based on part of speech: complementizers (and attached clitics) may appear initially, but the auxiliary and agreement clitics alone cannot. On this second possibility, number of syllables is irrelevant. Indeed, kapi does share the ability to appear initially with other complementizers, for example:

$$
\begin{aligned}
& \text { a. Kala-ka-rlipa-nyanu } \quad \text { mata-rra-ma-ni? } \\
& \text { PotentialC-PresImpf-1plIncl-AnaphObj tired-thither-Cause-Npast }
\end{aligned}
$$

But aren't we liable to tire ourselves? (Simpson 1991:163)

b. Kaji-lpa-ngku wanti-yarla nyiya-rlangu NfactC-PastImpf-2sgObj fall-Irr what-for.example milpa-kurra ... eye-All

If something were to fall into your eyes ... (Warlpiri Dictionary Project 1993)

However, these complementizers are also disyllabic, and so are also compatible with either explanation. The two possible explanations can be differentiated, though, by the behaviour of the relational complementizer $y i$, the only monosyllabic complementizer (there are no disyllabic auxiliaries). The explanation based on number of syllables predicts that $y i$ will not be able to appear initially, except when followed by a pronounced auxiliary (thus increasing the number of syllables before the agreement clitics to two). The explanation based on part of speech predicts that $y i$ will always be able to

\footnotetext{
${ }^{8}$ Semantically, kapi also fits more naturally into the complementizer series, which realizes a coherent subsection of Cinque's (1999) hierarchy of functional projections: T(Past), T(Future), $\operatorname{Mood}_{\text {irrealis }}$, Mood $_{\text {possibility }}$, Asp habitual . The auxiliaries, on the other hand, realize only perfective versus imperfective aspect (and perhaps tense; see Legate 2003b for arguments that the present/past distinction in the imperfective aspect is not interpreted).

${ }^{9} \mathrm{An}$ anonymous reviewer suggests that this generalization could be explained if the monosyllabic auxiliaries are clitics, whereas the complementizers are ambiguous between a clitic use and a nonclitic use. However, the complementizers do not have a clitic use, as indicated by the lack of vowel harmony effects between the complementizers and preceding material. See Section 3 for discussion.
} 
appear initially. The prediction based on part of speech is borne out; $y i$ may appear initially even without a pronounced auxiliary:

a. Yi-rna munga-wiri jiwin-pu-ngu.

RelationalC-1sgSubj all.night toss.and.turn-VF-Past

As I tossed and turned all night.

b. Yi-rlipa-jana ngangkayi-wanawana miyi

RelationalC-1plInclSubj-3plObj medicine.men-relating.to vegetable karla.

yam

So we can dig up yams for the medicine men. (Warlpiri Dictionary Project 1993)

I conclude that contrary to standard assumptions, syllable count is not relevant to the placement of clitics in Warlpiri. Instead, complementizers may appear initially in Warlpiri, while aspectual and agreement clitics may not.

\subsection{The connected speech generalization}

In this section I consider another argument that has been used to support a phonological approach to clitic placement in Warlpiri (see for example Anderson 2000; Billings 2002). The original observation is due to Simpson (1991:69): "in connected speech, monosyllabic AUX bases are found sentenceinitially, because the last element of the previous sentence provides a phonological host for the clitics." The following is an example from Hale (1966) (pc Jane Simpson to Steve Anderson); notice that the final sentence begins with the aspectual clitic $k a$ :

$\begin{array}{lll}\text { Jinarn-kiji-ni-ji. } & \text { Ngula-nya-ka-rnalu } & \text { ngarri-ni } \\ \text { trip-throw-NPast-Top } & \text { that-Foc-PresImpf-1plExclSubj call-NPast } \\ \text { jinarn-kiji-ni-ji, } & \text { kaji-lpa-npa } & \text { watiya-rla-rlangu } \\ \text { trip-throw-NPast-Top } & \text { NFactC-PastImpf-2sgSubj log-Loc-for.example } \\ \text { wanti-yarla. } \underline{\mathrm{Ka}} & \text { jinarn-kiji-ni. }\end{array}$

fall-Irrealis PresImpf trip-throw-NPast

Jinarn-kijirni. We call it jinarn-kijirni if you fall over on, say, a piece of wood, it trips one up.

However, caution must be used when drawing any conclusions from such examples. Certainly the transcription gives no indication that $k a$ is cliticized to the preceding word. Indeed, Laughren (2002) characterizes such examples as involving a pause between the preceding material and $k a$, casting doubt on such an interpretation.

More interesting perhaps is the possibility that the status of $k a$ as a clitic is in flux. ${ }^{10}$ Since the vowel /a/ is inert for vowel harmony, vowel harmony effects

\footnotetext{
${ }^{10}$ This is not possible for $l p a$, since prosodic words may not begin with the consonant sequence $l p$ in Warlpiri.
} 
provide no evidence for the clitichood of $k a$. And there is some evidence from secondary stress placement and from phonetics that $k a$ behaves differently from other clitics and affixes.

A sequence of monomoraic suffixes/clitics in Warlpiri receives secondary stress as follows: binary trochaic feet are built beginning with the initial monomoraic suffix; a final odd mora is unstressed (see Nash 1986; Kager 1995; Pensalfini 2000; Berry 1999, for further details of stress placement in Warlpiri). ${ }^{11}$ :
a. wáti-ngka man-Loc
b. wáti-ngkà-rlu man-Loc-Erg
c. wátiya-rlà-rlu tree-Loc-Erg
d. wátiya-rlà-rlu-ju tree-Loc-Erg-Top

However, when $k a$ appears in a sequence of monomoraic suffixes and clitics, it attracts stress: ${ }^{12}$
a. wángka-mi-kà-rna speak-Npast-PresImpf-1sgSubj
b. wángka-mi-kà-rna-ngkù-lu speak-Npast-PresImpf-1sgSubj-2sgObj
c. wángka-mi-kà-rna-ngkù-lu-rla speak-Npast-PresImpf-1sgSubj-2sgObj-3DatObj

In this, it resembles monomoraic roots, which bear stress regardless of position (Nash 1986):
(13) túrl-tùrl-ngà-rni split-split-eat-Npast

$k a$ behaves differently from roots, however, in that it does not bear stress if this would result in a monomoraic foot. One such context is when a bimoraic suffix or clitic follows; bimoraic suffixes and clitics bear initial stress in Warlpiri.

$$
\begin{aligned}
& \text { a. Wárlpirì-ka-rlìpa } \\
& \text { Warlpiri-PresImpf-1plInclSubj }
\end{aligned}
$$

\footnotetext{
${ }^{11}$ Stress placement in Warlpiri is overall more variable than the theoretical discussions generally acknowledge. This variability is partially addressed in Berry (1999), but further work is required. Variability that bears directly on the current discussion is discussed below.

${ }^{12}$ In contrast, lpa patterns with other clitics and suffixes:

(i) wátiya-rlà-lpa-jàna tree-Loc-PastImpf-3plObj

(ii) wángka-jà-lpa-rna speak-Past-PastImpf-1sgSubj 


\section{b. wángka-mì-ka-pàla speak-Npast-PresImpf-3DualObj}

Thus, the behaviour of $k a$ with respect to stress assignment is intermediate between a prosodic word and a clitic/suffix.

It must be noted that the patterns discussed here are those standardly reported in the literature. However, an anonymous reviewer notes that there is considerable inter- and intra-speaker variation on the behaviour of $k a$ for stress placement. ${ }^{13}$ For example, the reviewer suggests that the stress pattern shown in (14a) may be less frequent than one in which $k a$ bears stress, regardless of the following bimoraic suffix:

\section{Wárlpiri-kà-rlipa Warlpiri-PresImpf-1plInclSubj}

The reviewer also points out more dramatic word-like behaviour of $k a$ in examples from Ken Hale's fieldnotes in which $k a$ with no following enclitics bears a secondary stress mark. These provide further support for our suggestion that the status of $k a$ as a clitic is not secure.

In addition, Pentland (2004) documents phonetic strengthening of wordinitial consonants in Warlpiri (longer stop closure duration, and longer and stronger release bursts). Interestingly, she notes that the $/ \mathrm{k} /$ in $k a$ displays an unusually high frequency of consonant strengthening, more comparable to word-initial consonants than to word-medial. This is all the more striking in that Pentland's data involve $k a$ in second position. Again, as pointed out by an anonymous reviewer, we find variability here, with $k a$ sometimes undergoing voicing to $[\mathrm{g}]$ and even lenition to $[\gamma]$, as expected of a word-medial consonant. This type of variability is again expected on the current suggestion.

Finally, it is worth noting that $k a$ can bear contrastive focus, appearing initially in polarity focus clauses:
(16)
Ka-rna $\quad$ ya-ni. PresImpf-1sg.Subj go-Nonpast
I AM going.

In sum, attested examples of $k a$-initial clauses do not clearly support a phonological analysis of clitic placement in Warlpiri. There is no evidence

\footnotetext{
${ }^{13}$ The reviewer also reports having heard theoretically unexpected secondary stress on lpa: wángkaja-lpà-rna. As mentioned in footnote 11, Berry (1999) has some discussion of the variability of stress placement, but further work is required.
} 
of cliticization of $k a$ to an element in a preceding clause. In addition, the behaviour of $k a$ is sufficiently variable and idiosyncratic that there is reason to question the stability of the status of $k a$ as a clitic. Thus, $k a$-initial clauses bear further study, as does the behaviour of $k a$ more generally, but $k a$-initial clauses cannot provide evidence for a phonological analysis of clitic placement at the present level of understanding. In the remainder of the discussion I leave aside the issue of $k a$-initial clauses.

In the following section, I examine possible approaches to clitic placement in Warlpiri.

\section{Analyses}

A primary challenge in the analysis of clitic placement is the reconciliation of the surface position of the clitic with the expected position based on the clitic's syntactic function. For a subset of clitics, those which do not receive semantic interpretation, this issue may be sidestepped by claiming that the clitics have no syntactic function; since these clitics need not receive an interpretation, they may be inserted on the PF branch in the standard Y-model of grammar. ${ }^{14}$ Agreement clitics, for example, may fall into this class. This insertion may either be directly into the correct position, or at first into approximately the correct position, with subsequent mechanisms used to achieve correct placement. The analysis of clitic placement in the OptimalityTheory framework (Anderson 1995, 1996, 2000, 2004, 2005; Legendre 1998, $1999,2000 \mathrm{a}, \mathrm{b}, \mathrm{c})$ is of the former type. Clitics are inserted in a post-syntactic morphology into their surface position through ranked constraints specific to clitic placement. The analysis of clitic placement in the Distributed Morphology framework developed in Embick and Noyer (2001) is of the latter type. Clitics are inserted in a post-syntactic morphology at the edge of the projection in which they surface, ${ }^{15}$ with morphological inversion operations achieving the surface position.

Sidestepping the issue of expected syntactic position versus surface position in this way becomes problematic, however, when we consider clitics that do

\footnotetext{
${ }^{14} \mathrm{I}$ adopt the standard assumption that operations on the PF branch do not feed semantic interpretation on the LF branch; see Marantz (1995) for a dissenting view, and footnote 21 for related discussion.

${ }^{15}$ Elements inserted at this stage of the derivation are referred to as "dissociated" in Distributed Morphology. Although not all clitics are considered dissociated in this manner, the second position clitics considered in Embick and Noyer (2001) crucially are. The analysis provided in Section 4 also broadly assumes a Distributed Morphology framework.
} 
have a corresponding position in the syntax. These clitics realize features that receive a semantic interpretation (and thus must be present before the $\mathrm{PF}$ branch), and/or have an established projection in the structure of the clause. Auxiliary verb clitics, for example, belong in this class. For these clitics, to insert them at PF directly into (approximately) their surface positions is to claim that there is no relationship between the syntactic head and the corresponding clitic. But syntactic analysis is built on the basic assumption that pronunciation is closely related to surface structure - elements cannot be pronounced in complete disregard of their syntactic position, or syntactic analysis becomes impossible.

As discussed in the previous section, while the Warlpiri clitic cluster includes subject agreement and object agreement clitics which belong to the class that may plausibly be inserted at PF, they obligatorily cluster with clitics that realize tense/aspect features, and so have a corresponding syntactic position. Therefore, I take it as a given that the analysis of these clitics should include a syntactic component; that is, the syntax is responsible for placing the clitics in approximately the correct position. Later morphological operations may adjust that position slightly, but may not ignore the position established in the syntax.

Warlpiri also provides potential empirical support for this conclusion. The clitics are obligatorily hosted by the complementizers (when present); these complementizers are not themselves clitics. ${ }^{16}$ This is demonstrated by their failure to show the $u / i$ vowel harmony effects exhibited by clitics in the language. Examples follow for the declarative complementizer kuja: and the relational complementizer $y i:^{17}$

a. Ngamirlji, ngula-ji kuja-ka ngati-nyanu-rlu in.arms that-Top DeclC-PresImpf mother-AnaphObj-Erg marda-rni kurdu,... hold-NPast child

Ngamirl $j i$ is when a mother holds a child, ...
b. nganayi kuja-lpa-lu liwanja-paju-rnu, ...

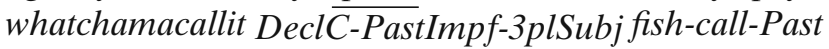
that thing they called fish,... (Warlpiri Dictionary Project 1993)

\footnotetext{
${ }^{16}$ Contra Anderson (2000), which proposes that Warlpiri complementizers come in two variants: a non-clitic that forms a phonological word and so may appear initially, and a clitic that does not form a phonological word, and so must appear in second position in order to be integrated into a preceding phonological word. (Note that Anderson 2000 assumes Hale's 1973 generalization.) This is compared to the situation of English is and has, which have both full and clitic forms. However, in the English case, the clitic forms are phonologically distinct from the full forms. This is not the case for the Warlpiri complementizers.

${ }^{17}$ Thank you to an anonymous reviewer for suggesting that I include examples involving $y i$.
} 
a. Jukarurru yi-lpa payi ya-nu-rnu straight RelC-PastImpf wind go-Past-hither nyanungu-kurra-juku - yujuku-kurra. 3sg-All-still humpy-All As the wind came straight towards it - towards the humpy.

b. Nantuwu yi-rna nganta yali puuly-marda-karla, horse RelC-1sgSubj supposedly yonder seizing-have-Irr ngula-ju wuruly-parnka-ja. that-Top hidden-run-Past

Just as I was about to grab hold of that horse it ran off. (Warlpiri Dictionary Project 1993)

If the complementizers were clitics, vowel harmony would have required *ngulaji kijaka and *nganayi kijalpalu in (17), and *yukarurru yulpa and *nantuwu yurna in (18).

Despite the fact that the complementizers are not clitics, they exhibit the same placement possibilities as the clitics alone, with the sole distinction that the complementizers may also appear initially. ${ }^{18}$ As discussed above, complementizers (and attached clitics) may appear either in initial or second position in Warlpiri:
a. Kapi-rna-ngku yimi-ngarri-rni.
FutC-1sgSubj-2sgObj story-tell-Npast
I'll tell you about it.
b. Jurru kapi-ngki kaarrkaarr-janka.
head FutC-2sgObj singe.Npast
It will singe your hair. (Warlpiri Dictionary Project 1993)

When the clause begins with an evidential marker, the clitics optionally appear in second or third position:

(20) a. Karinganta-rna kuyu-jarra yampi-ja-rni. fact-1sgSubj meat-Dual leave-Past-hither

The fact is I left two animals (I speared) and came here.

b. Karinganta miyi-wangu ka-rnalu-jana

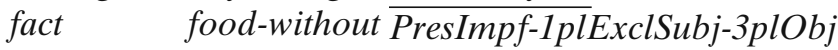

yarnunjuku nyina.

hungry sit.NPast

Isn't it obvious that we are waiting for them (here) hungry without any food? (Warlpiri Dictionary Project 1993)

This pattern extends to clauses with overt complementizers: the complementizer (and attached clitics) optionally appears second or third, as shown

\footnotetext{
${ }^{18}$ See Section 4.2 for a single exception.

Springer
} 
in (21). ${ }^{19,20}$ Note that the complementizer may not appear initially in such clauses, unlike in clauses without an evidential.

a. Kulanganta kapu-npa-ju yu-ngkarla.
counterfact FutC-2sgSubj-1sgObj give-Irrealis

I thought you would have given it to me (but you didn't).

b. Karinganta warnarrpi-rlangu-rlu

fact brother.in.law-kinship.pair-Erg

kapi-pala-nyanu jalangu-ju wajampa-ma-ni.

FutC-3dualSubj-AnaphObj now-Top injured-VF-Npast

My two brother-in-laws will fight each other now. (Warlpiri Dictionary Project 1993)

The shared placement possibilities for the complementizers and the clitics argues for a syntactic placement of the clitics - since the complementizers are not clitics, their surface position must be determined syntactically.

This shared placement of the clitics and the complementizer provides another suggestive argument for syntactic placement. Assuming a standard

\footnotetext{
${ }^{19}$ The optionality found in clitic placement in Warlpiri raises issues for the OT approach, which is based on the idea that clitics want to be as far to the left in a domain as possible, Edgemost $(\mathrm{Cl}$, L, D), without being initial, Non-Initial(Cl, D). Additional optionality is found in constructions involving an initial preverb; the clitics may optionally appear between the preverb and the verb, or following the preverb and verb, as shown here with the preverb rampal(pa) 'mistake' and the associated verb luwarnu 'shot':
}

(i) Rampal-luwa-rnu-rna-rla-jinta marlu-ku. mistake-shoot-Past-1sgSubj-3DatObj-3DatObj kangaroo-Dat

I shot at a kangaroo and failed.

(ii) Rampalpa-rna-rla-jinta luwa-rnu marlu-ku. mistake-1sgSubj-3DatO $b j-3$ DatObj shoot-Past kangaroo-Dat

I shot at a kangaroo and failed. (Laughren 1989)

A possible approach to these data would be to claim that the preverbs come in two variants, one that requires splitting and the other that disallows it. Such an approach finds potential support in the alternation between the consonant-final and augmented vowel-final form of certain preverbs, like rampal(pa) above. However, the augmented form of such preverbs is available independently of splitting:

(iii) Ramparlpa-ju ka-rnalu ngarri-rni ngula-ju yangka

mistake-Top PresImpf-1plExclSubj call-Npast that-Top like

kuja-ka-lu-rla ramparlpa parnka marlu-rlangu-ku.

DeclC-PresImpf-3plSubj-3DatObj mistake run.Npast kangaroo-for.example-Dat

We call it ramparlpa like when they go to get a kangaroo and fail. (Warlpiri Dictionary Project 1993)

In addition, whereas all preverbs exhibit the optionality of splitting, many preverbs lack a reduced consonant-final allomorph that would disallow splitting, for example, pirri 'scattered' and yarda 'again'. See Section 4.2 for further discussion of the preverb construction.

Approaches to the general problem of optionality in OT include partially ordered grammars (Anttila 2002), and stochastic ranking (Boersma 1998).

${ }^{20}$ In addition to its use as a clausal evidential marker, kulanganta can also directly modify a DP, optionally appearing on either side of the DP: 
inverted Y-model of the grammar, operations on the PF branch do not receive a semantic interpretation. Therefore, if the clitics were inserted on the branch towards PF, their position should have no semantic consequences. ${ }^{21}$ The clitics themselves, as aspectual and agreement markers cannot be tested. However, interpretive effects can be tested for the complementizers. Here I consider the negative complementizer kula, and the nonfact complementizer kaji.

One type of interpretive effect involves the interaction between clitics and negation. Laughren (2002) shows that kula differs from other complementizers in Warlpiri in that the position preceding kula cannot be interpreted as a focus position, although it can be interpreted as a topic position. ${ }^{22}$ Instead, focus must appear immediately following kula:
a. Ngaju kula-ka-rna
ya-ni.
I NegC-PresImpf-1sgSubj go-NPast
I'm not going. (subject topic, verb focus)
b. Kula-ka-rna ngaju ya-ni.
NegC-PresImpf-1sgSubj I go-NPast
I'm not going. (subject focus)

See Section 4.1 for further discussion of negation. Important for the present discussion is the fact that the position of the complementizer has an effect on the interpretation of the sentence.

This effect can also be seen in the interaction between negation and indefinites. For an indefinite to be interpreted in the scope of negation, it must follow the negative complementizer and attached clitics:
a. Kula-ka-rna
ngana nya-nyi.
NegC-PresImpf-1sgSubj who see-NPast
I don't see anybody.

(i) Nya-ngu-rna [kulanganta karnta] pirrarni-rli.

see-Past-1sgSubj counterfact woman yesterday-ERG

I saw what I thought to be a woman yesterday (but it wasn't a woman).

or:

(ii) Nya-ngu-rna [karnta kulanganta] pirrarni-rli.

see-Past-1sgSubj woman counterfact yesterday-ERG

I saw what I thought to be a woman yesterday (but it wasn't a woman).

Thank you to a reviewer for pointing out this additional use and providing these examples.

${ }^{21}$ Note that some work in Distributed Morphology (see, for example, Marantz 1995 explicitly denies that morphological operations on the PF branch cannot effect semantic interpretation. Instead, it is proposed that non-forced choices in the morphology are interpreted, in order to allow lexical roots to be inserted in the morphology. On such an account, the placement of clitics on the PF branch could have interpretative consequences when that placement involves choice. The assumption in the text holds only for those, like myself, who adopt a post-syntactic morphology while maintaining the standard inverted Y-model of grammar (thus rejecting late insertion of lexical roots), see for example Embick (2000), Chomsky (2001).

${ }^{22}$ Laughren (2002) also argues that negation originates in a lower position than other complementizers. 

b. Kula-ka-ngku ngana-ngku nya-nyi. NegC-PresImpf-2sgObj who-Erg see-NPast
Nobody sees you. (Hale 1976:70-71)
c. Kula-ka nyiya-rla nguna-mi kurdu. NegC-PresImpf what-Loc lie-NPast child
The child is not lying on anything.
d. Kula-ka ngana nyina-mi pirli-ngka.
NegC-PresImpf who sit-NPast stone-Loc
Nobody is sitting on the stone. (Hale 1976:49)

Since negative wh-questions are not possible in Warlpiri, positioning the indefinite to the left of negation is simply ungrammatical.

A similar effect is found with the nonfact complementizer kaji. Consider the following (from Laughren 2002):
a. Kaji-ka-rna
nyarrpara-kurra ya-ni
NFactC-PresImpf-1sgSubj where-All
go-NPast
I might go somewhere.
Where might I go?
b. Nyarrpara-kurra kaji-ka-rna ya-ni? where-All NFactC-PresImpf-1sgSubj go-NPast
* I might go somewhere.
Where am I likely to go?

Here we observe that although the non-fact complementizer kaji (often translated using 'if', 'might', 'when', 'while') may appear initially or in second position, the choice is not simply a matter of phonology. In order for nyarrpa 'where/somewhere' to be interpreted as an indefinite, it must follow kaji in the surface string.

In sum, placement of the clitics in Warlpiri must include a syntactic component. This allows for a non-arbitrary relationship between the clitics and associated syntactic projections, explains the shared placement possibilities of the clitics and the non-clitic complementizers, and allows the position of the complementizers to have interpretive consequences.

To begin the discussion of possible analyses, I will consider the simplest possible: one in which the clitics are located syntactically in a unique syntactic position.

\subsection{Unique syntactic position + prosodic inversion}

A simple approach to second position clitic placement identifies the position of the clitics with a unique syntactic position-the head of some (high) XP. Second positioning then is derived through obligatory filling of the unique specifier of XP. This type of analysis for Serbo-Croatian may be found in Franks and Progovac (1994), King (1996), Progovac (1996), Schütze (1994), 
Tomić (1996), Wilder and Ćavar (1994a, b). Such an analysis of Warlpiri is proposed by Austin and Bresnan (1996). ${ }^{23}$ Austin \& Bresnan place the clitics, and the complementizer, in the head of IP, and claim that Warlpiri lacks a CP. Their structure for Warlpiri is the following:

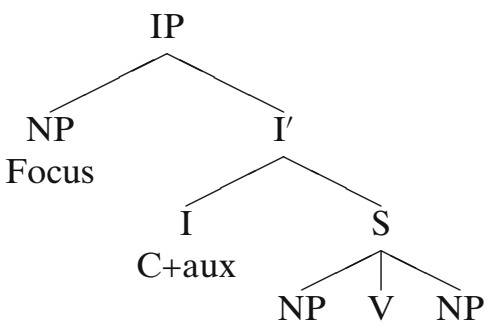

This analysis cannot be correct. The interaction between clitics and whphrases can be used to identify clitics in distinct syntactic positions in Warlpiri. ${ }^{24}$ Wh-phrases in Warlpiri do not exhibit freedom of ordering- to be interpreted as a wh-phrase, the phrase must appear in a left-peripheral position. If it fails to appear in this position, the phrase is interpreted as an indefinite. This is illustrated in (26). Notice that the (complementizer and attached) clitic cluster obligatorily follows the wh-phrase in (26a).
a. Nyiya-rlangu kaji-ka-lu nyina what-for.example NFactC-PresImpf-3plObj be.NPast wampana-piya-ju? spectacled.hare.wallaby-like-Top

What ones for example might be like the spectacled hare wallaby?

b. Kaji-lpa-ngku wanti-yarla nyiya-rlangu

NFactC-PastImpf-2sgObj fall-Irr what-for.example milpa-kurra ...

eye-All

If something fell into your eyes ... (Warlpiri Dictionary Project 1993)

*What might have fallen into your eyes?

\footnotetext{
${ }^{23}$ Halpern (1995) also proposes a unique syntactic position analysis of Warlpiri, but considers the clitics adjoined to IP. This seems less plausible, in that the aspect markers are heads rather than XPs. The problems raised in the text for Austin \& Bresnan's proposal carry over to Halpern's as well.

${ }^{24}$ Bošković (1995) argues that a unique syntactic position analysis cannot be correct for SerboCroatian either, his argument concerning the interaction between adverbs and participles. The crucial examples, however, likely receive an independent explanation; see Section 4.1 below.
} 
Wh-questions may also contain a topicalized phrase, ${ }^{25}$ in which case the topicalized phrase precedes the wh-phrase. Crucially, the clitic cluster must now precede the wh-phrase:

\author{
Kuturu-ju-ka-npa-nyanu \\ nyarrpara-wiyi \\ nullanulla-Top-PresImpf-2sgSubj-AnaphObj where-first \\ marda-rni? \\ have-NPast
}

Where do you have this nullanulla of yours? (Hale 1960:7.20-7.21)

So, when the wh-phrase in its left peripheral position happens to also be initial, the clitics follow it. However, when the projection hosting the wh-phrase is dominated by a topic projection, the clitics precede the wh-phrase. Thus, the clitics do not appear in a unique syntactic position in Warlpiri. ${ }^{26}$

In addition to the basic syntactic positioning, Austin \& Bresnan's analysis provides for a later operation to adjust the position of the clitics slightly when necessary. The operation they enlist is phonological, specifically Halpern's (1995) Prosodic Inversion. Prosodic Inversion inverts an enclitic in initial position with a following prosodic word, in order to provide the clitic with a host. ${ }^{27}$ This operation would apply for example in (28), in which the initial host for the clitics is a word rather than a phrase, and so could not occupy the specifier of IP.

$$
\begin{aligned}
& \text { Wangka-mi-ka-lu } \quad \text { Yurntumu-wardingki-patu. } \\
& \text { speak-NPast-PresImpf-3plSubj Yuendumu-habitant-Pl }
\end{aligned}
$$

The Yuendumu people are speaking. (Laughren 2002:[14])

\footnotetext{
${ }^{25}$ This topicalization is distinct from hanging topic left dislocation constructions, which are also available in Warlpiri. Unlike topicalized phrases, hanging topics cannot host the clitic cluster. An example of hanging topic left dislocation that minimally differs from (27) is given in (0i) (thank you to an anonymous reviewer for this example). See Legate 2002, 2003a for discussion of topicalization and hanging topic left dislocation in Warlpiri.
}

(i) Kuturu-ju, nyarrpara-wiyi ka-npa-nyanu marda-rni?

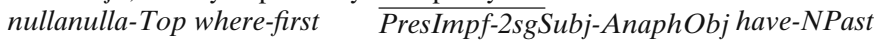
The nullanulla, just where do you have it?

\footnotetext{
${ }^{26}$ This point is also made in Laughren (2002).

${ }^{27}$ Whether clitics may appear after the first prosodic word of a larger constituent in SerboCroatian has been a matter of some debate: for example, Halpern (1995) argues that first word placement is possible, while Progovac (1996) and Wilder and Ćavar (1994a) argue that apparent first word placement can be reduced to first phrase; Schütze (1994) presents examples that appear problematic for a first phrase account, but the examples are disputed by Bošković (2001). In addition, Franks and Progovac (1994), Progovac (1996), Wilder and Ćavar (1994a, b), and Bošković (2001) present arguments against a Prosodic Inversion analysis for Serbo-Croatian.
} 
However, Prosodic Inversion, as phonological, is not the type of operation needed for Warlpiri. There are clear morphosyntactic limits on possible initial words in Warlpiri, which a phonological account cannot explain.

Consider noun phrases and (the equivalent of) postpositional phrases. Warlpiri allows these to be discontinuous in the syntax. However, there is unambiguous morphological evidence to distinguish between noun phrases that are syntactically intact and those that are split. When a noun phrase is intact, case marking is optional on non-final elements of the phrase. However, when a noun phrase is split syntactically, each piece of the noun phrase must bear final case marking (similar facts obtain in Serbo-Croatian, but are limited to multi-word names, see Franks 1997 and Bošković 2001). Thus, an element lacking appropriate case marking must form part of a larger DP projection. This generalization is illustrated in (29).

a. [Maliki wiri-ngki]-ji yalku-rnu. [dog big-Erg]-1 $\overline{s g}$.Obj bite-Past The/a big dog bit me.

b. Maliki-rli-ji yarlku-rnu wiri-ngki.

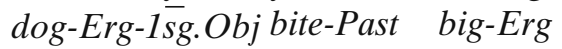

The/a big dog bit me. (Hale 1983:38)

c. *Maliki-rli-ji yarlku-rnu wiri. dog-Erg-1sg. Obj bite-Past big

The/a big dog bit me.

d. *Maliki-ji yarlku-rnu wiri-ngki. dog-1sg. $\bar{O}$ bj bite-Past big-Erg

The/a big dog bit me.

Using this morphological test, we find that Prosodic Inversion overgenerates in Warlpiri. Clitics may not appear after a prosodic word that forms part of a syntactically intact noun phrase. This is illustrated in (30). In (30a), kurdu yalumpu-rlu 'that child' must be a single, intact, noun phrase, since $k u r d u$ 'child' lacks case-marking. Cliticization to kurdu is ungrammatical. In (30b), on the other hand, 'child' bears case-marking, kurdu-ngku, allowing a parse in which the noun phrase has been split into two phrases. Thus, cliticization to kurdu-ngku is grammatical.

a. *Kurdu-ka-jana yalumpu-rlu maliki-patu jiti-rni. child-PresImpf-3plObj that-Erg dog-Pauc tease-NPast That child is teasing the dogs.

b. Kurdu-ngku-ka-jana yalumpu-rlu maliki-patu jiti-rni. child-Erg-PresImpf-3plObj that-Erg dog-Pauc tease-NPast That child is teasing the dogs. 
Austin \& Bresnan are aware of these data, and claim that (30a) is ruled out in the following way: "prosodic inversion is a 'last resort', according to Halpern (1995). We assume that this is what prevents the prosodic splitting of a caseless nominal component from a larger nominal constituent ... In this situation, the alternative always exists of placing a case-marked form of the nominal in the specifier of IP position" (1996:227-228). However, the alternative of placing a nominal in the specifier of IP also exists in (28), and yet here placement after the first prosodic word, a verb, is grammatical. In sum, the Prosodic Inversion operation, as phonological, cannot make the required distinction between a prosodic word that is a verb, which may host the clitics, and a prosodic word that forms part of a larger noun phrase, which may not host the clitics. ${ }^{28} \mathrm{We}$ return to the analysis of verb-initial clauses in Section 4 below.

Prosodic Inversion also under-generates in Warlpiri. Recall that overt complementizers and attached clitics may appear initially in Warlpiri. Therefore, the Prosodic Inversion analysis predicts that verb initial clauses should never have an overt complementizer: the clitics' requirement for a phonological host is met by the complementizer, and so Prosodic Inversion would not be triggered. This prediction is not borne out. Verb-initial clauses may have overt complementizers, as illustrated here by (55). This example begins with an adjoined dependent clause kuja palijalku 'when he died', followed by a pause; such adjoined elements are ignored for the purposes of clitic placement (see Sections 3.2 and 4.1 for further discussion). In the main clause, the verb waarrpakarnu 'hit many times' is initial, followed by the complementizer kala, and the clitic cluster lunyanu:

(31) (Kuja pali-ja-lku,) waarr-paka-rnu-lku DeclC die-Past-then, many.times-hit-Past-then kala-lu-nyanu nyanungu-rla-ju katu-mparra. Past $\overline{C-3 p l S u b j}$-AnaphObj 3sg-Loc-Top top-along.side (When he died,) they would beat themselves over him. (Warlpiri Dictionary Project 1993)

Such serious difficulties with the operation for Warlpiri invite the conclusion that Prosodic Inversion does not apply in the language. However, before reaching this conclusion, we must consider another apparent first word phenomenon that Austin \& Bresnan analyse using Prosodic Inversion: clauses in which a preverb is separated from the verb by the clitic cluster. An example of this

\footnotetext{
${ }^{28}$ For a similar point, see Laughren (2002).
} 
phenomenon, which I refer to as the "preverb split" construction, is provided in (32) ${ }^{29}$ In this example the preverb is yarda 'again'.

$$
\begin{aligned}
& \text { Yarda-lpa ya-nu. } \\
& \text { again-PastImpf go-Past }
\end{aligned}
$$

$\mathrm{He} / \mathrm{she} /$ it was going again. (Laughren 2002)

Warlpiri has a relatively impoverished set of verb roots, with much of the expressive burden being borne by nominal/adjectival ${ }^{30}$ elements adjoined to the left of the verb root. These often have a resultative interpretation, for example pirri-luwarni 'scattered-hit' 'strike and scatter'. These constructions will be examined in Section 4.2. It is important to note here, however, that the ability of preverbs to be separated from the verb by the auxiliary is lost in the gerundive form of the verb (Laughren 2002). This is illustrated here with the preverb yarda 'again' and the associated verb yani 'go':

$$
\begin{aligned}
& \text { a. } \quad \text { Yarda-ka-lu } \\
& \text { again-PresImpf-3plSubj go-NPast }
\end{aligned}
$$
They are going again.

b. *Yarda-ka-lu ya-ninja-ku ... again-PresImpf-3plSubj go-Infin-Dat (going again, they are ...) (Laughren 2002)

The phonological relationship between the preverb and the verb is unchanged in the gerund, forming a separate phonological domain from the verb for $u / i$ vowel harmony, while constituting part of the domain of the verb for primary stress assignment (see Nash 1986; Berry 1999; Harvey and Baker 2005, for discussion). This suggests that the phonology cannot make the required distinction between preverbs associated with a finite verb, which can participate in the split construction, and preverbs associated with a gerund, which cannot.

Finally, in the preverb split construction, consonant-final preverbs appear with a final CV suffix; this allows them to satisfy the condition in Warlpiri that all prosodic words must end in a vowel. Significantly, this suffix must be added

\footnotetext{
${ }^{29}$ The phenomenon is also discussed by Laughren (2002), who refers to it as "aux straddling". Laughren proposes a syntactic movement account; as we will see below, this type of account is unable to explain the full range of data, in particular the possibility for semi-productive preverbs to participate in the construction.

${ }^{30}$ The distinction between nouns and adjectives in Warlpiri is quite difficult to make, see Bittner and Hale (1995) for discussion.
} 
in the morphology rather than the phonology. The choice of suffix is lexically determined; while most preverbs appear with $p a$, a subset select for $k i$ :
a. jaaly(pa) 'whispering', jamparl(pa) 'chewing', kanginy(pa) 'ignorant', karlirr(pa) 'swerving', paarr(pa) 'into the air', tiirl(pa) 'split', ...
b. liirl(ki) 'white', miril(ki) 'shine', larlarl(ki) 'up high', ...

Note also that the problem of consonant-final prosodic words is resolved in the phonology in a different manner: through epenthesis of $-i$ (or $-u$ if required by vowel harmony). This can be observed through loan words from English:

$\begin{array}{ll}\text { yard } & \text { yarti } \\ \text { truck } & \text { turaki } \\ \text { rubbish } & \text { rapiji } \\ \text { machine } & \text { majini } \\ \text { bullock } & \text { puluku } \\ \text { nannygoat } & \text { nanikutu } \\ \text { mule } & \text { miyurlu }\end{array}$

Indeed, / $\mathrm{i} /$-epenthesis is a more expected phonological repair strategy to eliminate a word-final coda, rather than $\mathrm{pa} / \mathrm{ki}$ suffixation.

Given that the final suffix is inserted in the morphology, this indicates that the preverb must already be split from the verb in the morphology. Again I conclude that the split cannot be produced through a phonological operation like Prosodic Inversion.

In summary, the analysis of Warlpiri clitic placement in Austin and Bresnan (1996) was of the right type, in positing basic syntactic placement of the clitics, combined with a later operation slightly adjusting this position. However, it is problematic in two respects. First, it incorrectly claims that the clitics occupy a unique syntactic position. Second, it uses a phonological mechanism to adjust clitic placement, rather than morphological.

In the following section, I turn to another possible analysis of clitic placement, which also includes an initial syntactic component, followed by a morphophonological repair operation.

\subsection{Weak phonological approach}

Bošković (2001) develops an approach to second position clitic placement that he characterizes as a weak phonological approach, focusing on SerboCroatian. On Bošković's analysis, clitics undergo movement in the syntax, with the results being filtered or repaired in the phonology.

According to this approach, clitics are lexically equipped with conflicting demands: (1) the clitic must be initial in its intonational phrase; and (2) the clitic is a suffix. This closely resembles the OT account mentioned above (in the introduction to Section 3 and in footnote 19), whereby a constraint requiring the clitic to be leftmost in a domain, $\operatorname{Edgemost}(\mathrm{Cl}, \mathrm{L}, \mathrm{D})$, competes with a constraint requiring the clitic to not be initial, NonInitial(Cl, D). However, 
the weak phonological approach does not rank these conflicting requirements; instead, it claims that they may be satisfied simultaneously. After affixation of the clitics to a preceding word, the entire word inherits the clitics' requirement to be initial in its intonational phrase. Thus, if the host of the clitics is initial in the intonational phrase, that will satisfy the clitics' requirement. Furthermore, adopting Marantz' (1988) proposal that the head of a constituent at PF is the most peripheral element in the constituent, the weak phonological approach claims that the requirements of a word may be satisfied by the phrase it heads. Thus, when a clitic suffixes onto the final word of a phrase, the clitic's requirement that it must be initial in its intonational phrase is transferred to the final word. Since this word is the PF head of the phrase, its requirements can be satisfied by the whole phrase. Thus, suffixation onto the final element of a phrase that is initial in its intonational domain allows the clitic to count as initial.

Primary placement of clitics is accomplished through optional syntactic movement, the results of which are filtered by the lexical requirements of the clitics as discussed. In addition, a major theme of the book is the claim that the head of a movement chain need not be pronounced. Adopting the copy theory of movement (Chomsky 1993), Bošković argues that if forced by phonological requirements, a copy lower in the chain may be pronounced (see for example Groat and O'Neil 1996; Pesetsky 1997; Franks 1998; Bobaljik 2002, for various uses of lower copy pronunciation). Thus, if the output of the syntax includes initial enclitics, lower copies may be pronounced in order to satisfy the clitics' suffixal requirement.

Data involving the positioning of the clitics in later than second position appear problematic for a weak phonological analysis of Warlpiri, however caution must be taken. The analysis crucially refers to the intonational phrase rather than the clause. Thus such examples are only problematic in so far as the clitics are also later than second position in their intonational domain. Certainly, there are constructions in which clitics appear later than second position in the clause, but second in their intonational domain. Hanging topic left dislocation constructions constitute such a case; the left dislocated topic induces clitic third, however an intonational phrase boundary follows the left dislocated topic, rendering the construction irrelevant to the current discussion (see Legate 2002, 2003a, for discussion of hanging topic left dislocation in Warlpiri).

Wawirri, ngula ka nyina walya-ngka-jala. kangaroo, that PresImpf be.NPast ground-Loc-actually

The kangaroo, it lives on the ground. (Warlpiri Dictionary Project 1993)

There has been little work on intonational phrases in Warlpiri, however two recent instrumental analyses by Butcher (2003a, b) and Berry (1999) are 
relevant. These identify a characteristic tune for the (declarative) intonational phrase, with a high onset falling to a low final boundary tone. In addition, in casual speech, the intonational phrase constitutes a single primary stress domainthe initial primary stress is maintained, while following primary stresses are realized as secondary stresses. I rely on these tests here. Recall from above that complementizers in Warlpiri are not clitics, and do not suffix to a preceding word (see (17)). Therefore, on the weak phonological account, suffixation of the clitics to the complementizers will allow the clitics to satisfy their initial requirement only if the complementizer is itself in initial position. Clauses with the complementizer and attached clitics in second position should violate the initial requirement of the clitics. As mentioned previously, such examples are grammatical, and Berry (1999) shows that they constitute a single intonational domain based on the above criteria. An example from Berry (1999) follows, in which the relational clitic $y i$ and attached clitics follow the initial phrase nyampurla 'here':

$$
\begin{aligned}
& \text { Nyampu-rla-lku yi-rna purra-mi. } \\
& \text { here-Loc-now }
\end{aligned}
$$

I'm here now to cook. (Berry 1999)

Such clauses indicate that a weak phonological approach cannot be extended to Warlpiri.

Consider in addition the placement of the complementizers. The weak phonological approach is explicitly designed to account for the placement of clitics. Indeed, it makes crucial use of the suffixal nature of the clitics in the analysis of second position. Therefore, the approach could not explain the placement of the complementizers in Warlpiri, which are not clitics (see above). However, as we have seen, the distribution of the complementizers is almost identical to that of the clitics: both complementizers and clitics may appear in second position (after a phrase or a verb), both optionally appear in third position in the presence of an initial evidential, and neither may appear later in the clause. They differ in that the complementizers may appear initially, whereas the clitics may not-unsurprisingly given the enclitic nature of the clitics. ${ }^{31}$ Thus, an analysis of the clitic placement in Warlpiri should also explain the parallel behaviour of the complementizers.

Finally, we turn to the repair mechanism posited by the weak phonological approach: lower copy pronunciation. Clitics may be pronounced in a non-head position of the chain formed through their syntactic head movement. Reordering of elements, other than achieved through lower copy pronunciation, is

\footnotetext{
${ }^{31} \mathrm{~A}$ further distinction is that the clitics may intervene between a preverb and verb, whereas the complementizer may not. This is discussed and analysed in Section 4.2.
} 
explicitly disallowed. This predicts that the clitics may only be pronounced in a position they may occupy in the syntax. Consider in this light the preverb split construction. The preverb split construction involves pronunciation of the clitics inside the preverb-verb unit, thus the question becomes whether aspect, subject agreement, and object agreement could occur in this position syntactically. Detailed syntactic analysis of the preverb construction is beyond the scope of this paper, however we may make some observations that are relevant for the present discussion. For many preverbs that participate in the preverb split construction, it is clear that they originate low in the verb phrase, as they are crucially involved in theta-role assignment. One such example involves the verb mani 'get' used as a (causative) light verb when combined with a preverb. For example, in (30) mani is combined with the nonfinite verbs used as preverbs yulanjaku 'to cry', and wangkanjaku 'to speak'.

$$
\begin{aligned}
& \text { a. Kaji-ka-ju juju-ngku } \\
& \text { PotC-PresImpf-1sgObj evil.being-Erg } \\
& \text { yula-nja-ku-yula-nja-ku-ma-ni. } \\
& \text { cry-Infin-Dat-cry-Infin-Dat-get-NPast } \\
& \text { The evil one can make me cry. } \\
& \text { b. Ngaka-lu-jana wangka-nja-wangu-rla, } \\
& \text { later-3plSubj-3plObj speak-Infin-without-Loc } \\
& \text { wangka-nja-ku-wangka-nja-ku-ma-nu. } \\
& \text { speak-Infin-Dat-speak-Infin-Dat-get-Past }
\end{aligned}
$$

Later although they were not supposed to speak to them, they made them speak. (Warlpiri Dictionary Project 1993)

In other preverb-verb combinations, the verb functions as a light verb expressing inchoative or stative semantics, while the lexical content is contained in the preverb. The following examples involve the light verb jarrimi and the preverbs mata 'tired', and lani 'afraid':

a. Wurnturu-rla-rna mata-rni-jarri-ja ya-ninja-rla. far-Loc-1sgSubj tired-hither-Incho-Past go-Infin-Loc

I have gone a long way and have become tired.

b. Lani-jarri-mi ka Jampijinpa kuuku-ku-ju, afraid-Incho-NPast PresImpf Jampijinpa bogey.man-Dat-Top Jangala.

Jangala

Jampijinpa is afraid of the bogey-men, Jangala.

Another example of preverbs that must originate low in the verb phrase are those with resultative semantics. Although the analysis of resultatives is much debated, there is agreement on the placement of resultative predicates within the verb phrase. Examples with the resultative preverbs tiirl 'split', larra 'cracked', and jurnpu 'piled up' follow: 
a. Tiirl-paka-rni ka-rnalu - warlu-ku. split-strike-NPast PresImpf-1plSubj fire-Dat We split it for firewood.

b. Jirrima-lku ka larra-pi-nyi yangka-ju watiya two-then PresImpf cracked-hit-NPast that.one-Top tree jinta-jangka. one-from Then one tree is chopped into two.

c. Wantawanta ka-lu jurnpu-pangi-rni, rdaku wiri red.ant PresImpf-3plSubj piled.up-dig-NPast hole big

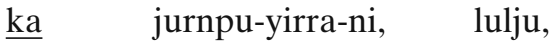
PresImpf piled.up-place-NPast mound.of.dirt

Red ants dig mounds, they dig out a big hole and pile up the dirt ... (Warlpiri Dictionary Project 1993)

These types of preverbs participate in the preverb split construction. (41) illustrates a sequence involving the preverb yitaki 'tracked' combined with the light verb mani; in the first sentence the preverb and verb occur together before the clitics, while in the second sentence the preverb is split from the verb by the clitics. (42) illustrates a preverb split construction with the preverb mata 'tired' and the light verb jarrimi. (43) shows use of nyarrpa 'how' as a preverb with the light verb jarrimi, first with the preverb and verb before the clitics, and then with the preverb split from the verb by the clitics.

$\begin{array}{lcc}\text { Yitaki-ma-nu-jana. } & \text { Yitaki-rra-jana } & \text { ma-nu } \\ \text { tracked-get-Past-3plObj tracked-Thither-3plObj get-Past }\end{array}$ parnman-kurlangu-rlangu kuja-lpa-lu ya-nu.

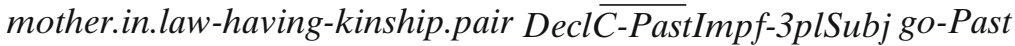

He followed their tracks. He went off tracking his mother-in-law and his wives, following where they had gone. (Warlpiri Dictionary Project 1993)

(42) Wurnturu ka ya-ni, mata-lku ka jarri. later PresImpfgo-Pres tired-then PresImpf become.NPast

He goes a long way, and then gets tired. (Warlpiri Dictionary Project 1993)

a. Nyarrpa-jarri-mi ka-lu Yurntumu-wardingki-patu? how-Incho-NPast PresImpf-3plSubj Yuendumu-habitant-Pl

What are the Yuendumu people doing? (Laughren 2002)

b. Nyarrpa-rlipa jarri?

how-1plincl become.NPast

What shall we become? OR What shall we do? (Warlpiri Dictionary Project 1993) 
Thus, the preverbs originate in the verb phrase and form a unit with the inflected verb, reflected phonologically by the verb and preverb forming a single domain for primary stress (as discussed in Section 3.1 above), and reflected syntactically by the ability for the verb and preverb to appear together before the clitic cluster. Whether this unit is formed through base generation or movement internal to the verb phrase is immaterial to the present discussion.

Consider now the merged position of the aspectual clitics, $k a$ and lpa, which express present imperfective and past imperfective respectively, and which contrast with the $-\varnothing$ perfective. These aspectual clitics have scope over the whole event rather than the verb or preverb alone, as illustrated in the following with the preverb-verb combinations pirri-karrka 'scattered-walk', pirringunami 'scattered-lie', jakati-wapaja 'leaving-walked', and jakajaka-manu 'singing spell-got':
a. Kuyu-ku ka-nkulu nyurrurla pirri-karrka meat-Dat PresImpf-2plSubj you.pl scattered-walk.NPast karnta-karnta.
woman-woman

You women are each going out to (look for) meat.

b. yangka kuja-ka-lu pirri-nguna-mi manu

like DeclC-PresImpf-3plSubj scattered-lie-NPast and

pularra-nguna miyi manu kuyu kiji-rninja-warnu.

scattered-lie.NPast food and meat throw-Infin-after

... so that the food and meat lies scattered after being thrown.

c. Jakati-jakati-lpa-lu wapa-ja yama-ngurlu.

leaving-leaving-PastImpf-3plSubj walk-Past shade-El

They would leave the sunshelter.

d. Jakajaka-ma-nu-lpa-nyanu-rla juju-ngku. singing.spell-get-Past-PastImpf-AnaphObj-3DatObj evil.one-Erg

The evil one was singing a spell for herself. (Warlpiri Dictionary Project 1993)

This suggests that the aspectual clitics originate in a position with scope over the verb and preverb. This positioning is expected on crosslinguistic grounds; imperfective and perfective aspect are referred to in the literature as viewpoint aspect (Smith 1991) or outer aspect (Verkuyl 1989), positioned syntactically between the verb phrase and TP (Kratzer 1998; Matthewson 2002; Ramchand 2004; Zagona 2004, among many others).

If this discussion is on the right track, the preverbs and verbs originate in the verb phrase and form a syntactic and phonological unit, while the aspectual clitics originate outside the verb phrase. This makes it unlikely that a syntactic copy of the aspectual clitic could appear between the preverb and the lexical verb; thus the weak phonological approach, which admits no alternative mechanism for clitic placement than pronunciation of syntactic copies, would 
wrongly predict clitic split constructions to be impossible. ${ }^{32}$ Further research is needed to explore these issues in more detail, however, it appears that the preverb split construction is problematic for the theory as well.

To conclude, the weak phonological approach is not directly applicable to Warlpiri. However, discussion of this theory has revealed that Warlpiri clitics may appear later than second in their intonational phrase, and that they may appear in a position that they never occupy in the course of the syntactic derivation (between a preverb and verb).

In the following section, we develop an alternative analysis of the Warlpiri data, combining syntactic movement with limited morphological reordering.

\section{Syntax plus morphology}

\subsection{Syntax ...}

In this section we develop an analysis of Warlpiri second position clitic placement, building on Laughren's (2002) head movement analysis (see also Franks 1998 for Serbo-Croatian).

Results from previous sections are instructive. The clitics are invariably suffixed to the complementizer, when present. Thus, the key to understanding clitic placement in Warlpiri is understanding the placement of the complementizer. We have demonstrated that the complementizer is not a clitic, failing to undergo the vowel harmony exhibited by clitics (Section 3). We have also demonstrated that the complementizer is placed syntactically, since

\footnotetext{
${ }^{32} \mathrm{An}$ anonymous reviewer suggests that the weak phonological approach could account for these data by pronouncing the highest copy of the preverb and clitics, but a lower copy of the verb. This approach seems unlikely to resolve the problem. First, pronouncing the verb in a lower position would allow for a specifier position between the preverb and clitics and the verb, predicting that an XP could appear between them, contrary to fact. In addition, lower copy pronunciation is constrained in applying only to resolve a PF violation; however no PF violation would result from pronouncing the verb in the higher position. As we have noted, it is also grammatical for the preverb and verb to appear before the clitics. An example showing this optionality is repeated here:
}

(i) Rampal-luwa-rnu-rna-rla-jinta marlu-ku. mistake-shoot-Past-1sgSubj-3DatObj-3DatObj kangaroo-Dat I shot at a kangaroo and failed.

(ii) Rampalpa-rna-rla-jinta luwa-rnu marlu-ku. mistake-1sgSubj-3DatObj-3DatObj shoot-Past kangaroo-Dat I shot at a kangaroo and failed. (Laughren 1989) 
its position has semantic consequences (Section 3). Finally, we have shown that the position of the clitics is non-uniform, dependent on the syntactic projections present in the sentence (Section 3.1).

We propose that the complementizer undergoes syntactic head movement to its surface position, based on the operation of Attract (Chomsky 1995). Thus, it is the properties of each functional head that motivate movement of the complementizer. We adopt the partial structure for Warlpiri in (45), adapted from Legate (2002). ${ }^{33}$

$($ EvidentialP $)>($ TopicP $)>($ FocusP $)>\mathrm{CP}>\mathrm{TP}>$ AspectP

For concreteness, I posit an [EPP $\left.\mathrm{Eead}_{\text {Hea }}\right]$ feature on certain functional heads, that is an EPP feature that is satisfied by adjunction of a head to the functional head bearing the feature. This feature simply encodes the need for head movement. In (45), T, C, as well as Focus and Topic when present, have the [EPP $\mathrm{Eead}_{\text {] }}$ ] feature, attracting Aspect to T, T to C, C to Focus, and Focus to Topic. The status of the agreement clitics in Warlpiri is controversial due to the purported nonconfigurational nature of the language. (For related discussion see for example Hale 1983; Jelinek 1984; Laughren 1989; Speas 1990; Legate 2002, among many others.) While abstracting away from this issue, I point out that my analysis requires that the agreement features form part of the complex head $\mathrm{C}+\mathrm{T}+$ Aspect before the application of morphophonology, and that subject agreement features be closer to $\mathrm{C}$ than object agreement features. I note that this may be achieved straightforwardly through syntactic head movement, but

\footnotetext{
${ }^{33}$ Whether the projections hosting topics and foci should be designated projections or recursive CPs is immaterial to the present discussion. On Rizzi's (1997, and subsequent) analysis of the left periphery, CP here would correspond to FinP. Note that the Warlpiri CP is demonstrably lower than FocusP (and so should not be identified with Rizzi's ForceP), since focus precedes the complementizer (in the absence of a topic). Examples follow; note that the wh-phrase nyiya 'what' precedes the declarative complementizer kuja.
}

(i) Wayipurru-rnu-lpa-lu miyi yawakiyi. Nyiya-kurra kuja-lu ma-nu? gather-Past-PastImpf-3plSubj fruit wild.currant what-All DeclC-3plSubj get-Past They gathered up the wild currants. What was it that they gathered them into?

(ii) Nyarrpara-rlu kuja panti-rni?

How-Erg DeclC spear-NPast

How to spear it? (Warlpiri Dictionary Project 1993) 
leave the issue aside. ${ }^{34}$ In all following trees, we place AgrS and AgrO as heads adjoined below Aspect for ease of exposition.

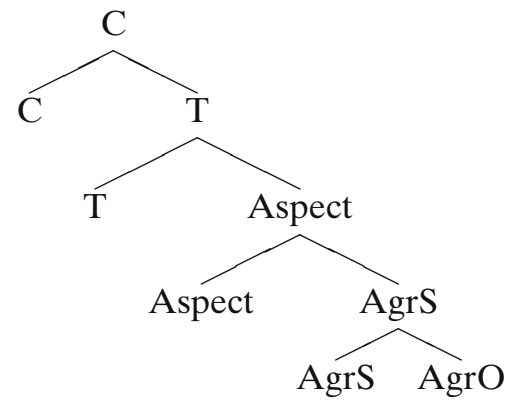

${ }^{34}$ The relative ordering of AgrS and Aspect is perhaps more interesting. Various possibilities arise. Aspect may be itself the syntactic host of the subject agreement features. Subject agreement may be added to Aspect in the morphology, thus functioning as a "dissociated morpheme" (see Embick 1997). Subject agreement features may head a functional projection below Aspect. Related is the issue of the Tense head in Warlpiri. The clitics we have been calling Aspect inflect for both tense and aspect, opening up the possibility that Tense and Aspect may form a single head in Warlpiri. See (6), Section 4.2, and Legate (2003b) for related discussion.

In addition, the morphology plays a role in the internal ordering of the agreement clitics. For many clitics, person and number are realized in a single portmanteau clitic. However, some clitics are analysable into separate person and number morphemes, including the subject clitics rna-lu ' 1 st person plural exclusive', $n k u$-lu '2nd person plural', and $l u$ '3rd person plural', which all contain the plural morpheme $l u$. Similarly, npa-pala '2nd person dual subject', ngku-pala '2nd person dual object', and pala '3rd person dual subject' contain the dual morpheme pala. When these subject clitics cooccur with the object clitics $j u$ '1st person singular', or $n g k u$ '2nd person singular', the subject number morpheme inverts with the object person morpheme:

(i)

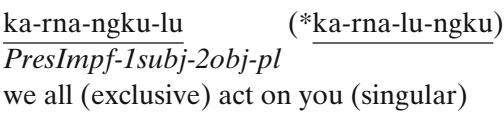

(ii)

$\frac{\text { ka-npa-ju-pala }}{\text { PresImpf-2subj-1obj-dual }}$

you two act on me

(iii) ka- Ø-ju-pala (*ka-pala-ju)

$\overline{\text { PresImpf-3subj-1obj-dual }}$

they two act on me

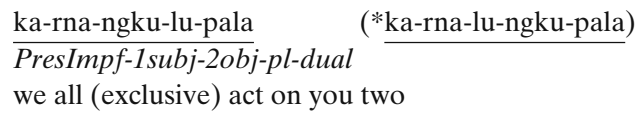

Thus, for these forms person clitics precede number clitics, and within each group subject clitics precedes object clitics. See Hale (1973) for further discussion, including discussion of morphological cooccurrence constraints on subject and object agreement clitics. (Halle 1997 is a recent discussion of the Warlpiri agreement system, however that work contains an error regarding the Warlpiri paradigm, inverting inclusive and exclusive agreement morphemes. The correct paradigm may be found in Hale et al. 1995.) 
First, we consider the internal morphophonological properties of this complex head, then we consider its placement in second position. We assume that syntactic representations are unordered, linearization being accomplished in the morphological component on the PF branch of the grammar. Ordering principles determine the linearization, with more specific ordering principles taking precedence over more general. In (46) the following linearization principle applies (where ' $*$ ' indicates the precedence relation): ${ }^{35}$

$$
\overbrace{X \quad Y}^{X} \rightarrow X * Y
$$

Morphologically, the lexical entries for AgrO, AgrS, and Aspect are all suffixal. There is no independent $\mathrm{T}$ morpheme, although Aspect shows allomorphy for T: $k a$ 'present imperfective' lpa 'past imperfective' (see below for further discussion of tense morphology). Thus, each head suffixes to the dominating head, resulting in the $\mathrm{C}+(\mathrm{T})+\mathrm{Asp}+\mathrm{AgrS}+\mathrm{AgrO}$ order.

Phonologically, the clitics lack structure at the level of the phonological word (on such a prosodic deficiency for clitics see for example Berendsen 1986; Selkirk 1986, 1995; Zec 1988; Inkelas 1989; Anderson 2005, among others), although bimoraic clitics do exhibit foot structure (see the discussion of stress in Section 3 and the references cited therein).

As discussed in Sections 2.1,2.2, and 3.1 above and references therein, the clitics form a single domain with their host word for vowel harmony and main stress assignment. However, as discussed in Section 2.2, the host of the clitic forms a domain independent of the clitic for an additional requirement, that phonological words must end in a vowel. We propose that the clitics adjoin to

\footnotetext{
${ }^{35} \mathrm{On}$ a theory in which ordering is present in the syntax, the linearization principle here would be expressed as right adjunction. An alternative would be to claim that $\mathrm{C}$, Aspect (and AgrS, AgrO) occupy the heads of distinct syntactic projections, and yet are uniformly syntactically adjacent (e.g. the associated specifiers are always empty). Such an analysis seems to me very difficult to maintain, particularly in light of the interaction between topic, focus and clitic placement discussed in Section 3.1. I leave any pursuit of such an analysis to others.
} 
the preceding phonological word in the following structure (cf Selkirk's 1995 affixal clitics): ${ }^{36}$

$$
\overbrace{\mathrm{PWd}_{1} \quad \overbrace{\text { clitic }}}^{\mathrm{PWd}_{1}}
$$

The full range of heads may not be overt in every clause, since each of these heads has a possible $\varnothing$ realization: matrix, declarative $\mathrm{C}$ is typically null; perfective Aspect is null; third person singlular AgrS and AgrO are both null. When the complementizer is overt, the phonological word in (48) will be the complementizer, otherwise it will be the preceding phonological word, whatever it may be.

Turning to the external placement of the complementizer plus clitic cluster, let us consider several sample derivations, building up complexity as we go. First, a simple wh-question:

$$
\begin{aligned}
& \text { Nyarrpara-kurra ka-npa } \\
& \text { where-All }
\end{aligned} \frac{\text { ya-ni? }}{\text { PresImpf-2sgSubj go-NPast }}
$$

Where are you going? (Warlpiri Dictionary Project 1993)

\footnotetext{
${ }^{36}$ The properties of phonological words in Warlpiri may thus be summarized as follows:

- vowel harmony: applies to the maximal Phonological Word dominating no distinct Phonological Words

- main stress: applies to a Phonological Word undominated by a Phonological Word

- vowel-finality: applies to a Phonological Word undominated by a distinct Phonological Word
}

Thus, for example, in the preverb compound construction:

(i)

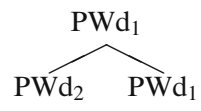

$\mathrm{PWd}_{2}$ and the smallest $\mathrm{PWd}_{1}$ are domains for vowel harmony. The largest $\mathrm{PWd}_{1}$ is a domain for primary stress. Both segments of $\mathrm{PWd}_{1}$ are domains for vowel-finality.

In constrast, for simple cliticization:

(ii)

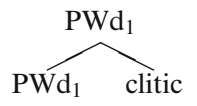

the largest $\mathrm{PWd}_{1}$ is a domain for vowel harmony, and for main stress. Both segments of $\mathrm{PWd}_{1}$ are domains for vowel-finality.

See Pentland and Laughren (2004) for an alternative, which decomposes the Phonological Word into two distinct levels: the Prosodic Word and the Phonological Word. 
Aspect ( $k a$ 'present imperfect') is attracted by the $\left[\mathrm{EPP}_{\text {Head }}\right]$ feature of $\mathrm{T}$, and raises to $\mathrm{T}$. The $\left[\mathrm{EPP}_{\text {Head }}\right]$ feature of $\mathrm{C}$ attracts and $\mathrm{T}+\mathrm{Aspect}$ raise to $\mathrm{C}$; subsequently the $\left[\mathrm{EPP}_{\text {Head }}\right]$ feature of Focus attracts and $\mathrm{C}+\mathrm{T}+\mathrm{Aspect}$ raises to Focus. In other words, head movement applies from Aspect through to Focus. In addition, Focus attracts the wh-phrase nyarrparakurra 'to where' to its specifier.

Adding a TopicP results in the following:

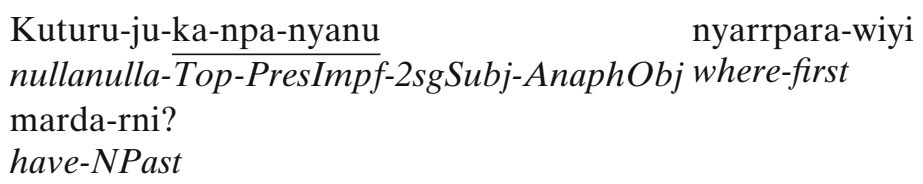

Kuturu-ju-ka-npa-nyanu nyarrpara-wiyi nullanulla-Top-PresImpf-2sgSubj-AnaphObj where-first marda-rni? have-NPast

Where do you have this nullanulla of yours? (Hale 1960:7.20-7.21)

The derivation proceeds as above to FocusP. Subsequently, the $\left[\mathrm{EPP}_{\text {Head }}\right]$ feature of Topic attracts and Focus $+\mathrm{C}+\mathrm{T}+$ Aspect raises to Topic, that is head movement continues to Topic. Thus, we obtain the result that the clitics do not surface in a unique syntactic position. In addition, Topic attracts the topic kuturuju 'nullanulla' to its specifier.

Consider a hanging topic left dislocation construction, containing a TopicP but no FocusP:

\section{Wawirri, ngula-ka nyina walya-ngka-jala. kangaroo, that-PresImpf be.NPast ground-Loc-actually}

The kangaroo, it lives on the ground. (Warlpiri Dictionary Project 1993)

As in the previous case, the $\left[\mathrm{EPP}_{\text {Head }}\right]$ feature of Topic attracts, and $\mathrm{C}+\mathrm{T}+$ Aspect raises to Topic. In addition, Topic attracts the topic ngula 'that' to its specifier. The hanging topic wawirri is adjoined to TopicP. ${ }^{37}$

Consider a derivation with no functional projections above $\mathrm{CP}$. The $\left[\mathrm{EPP}_{\text {Head }}\right]$ feature of $\mathrm{C}$ attracts, and $\mathrm{T}+\mathrm{Aspect}$ raises to $\mathrm{C}$. If $\mathrm{C}$ is pronounced, the complementizer plus attached clitics appear initially in the clause. If $\mathrm{C}$ is not pronounced, the clitics will appear initially without a host and the derivation will fail to converge. Thus, we differ from Halpern (1995) and Bošković (2001) in maintaining that derivations resulting in initial enclitics are filtered out, rather than triggering morphophonological repair operations. ${ }^{38} \mathrm{~A}$ smaller clause may be possible, lacking functional projections above TP. On such a derivation, $\mathrm{T}$ attracts Aspect to raise to $\mathrm{T}$; the derivation will converge, provided that the specifier of TP is occupied.

On this analysis, second position is epiphenomenal, driven solely by the properties of functional projections present in the clause. This is supported by clauses with overt evidentials. These were discussed above as problematic

\footnotetext{
${ }^{37} \mathrm{We}$ leave open the possibility that there exists a unique highest functional projection present in every clause-a (potentially null) EvidentialP, or a projection like Rizzi's ForceP that would be uniformly null. If so, hanging topics would adjoin to this projection.

${ }^{38}$ See Section 4.2 for a limited exception. 
for potential alternative accounts. Evidentials optionally host the clitics, and optionally trigger clitic third; examples illustrating this behaviour with the factive evidential karinganta are repeated below:

a. Karinganta-rna kuyu-jarra yampi-ja-rni.

fact-1sgSubj meat-Dual leave-Past-hither

The fact is I left two animals (I speared) and came here.

b. Karinganta miyi-wangu ka-rnalu-jana yarnunjuku

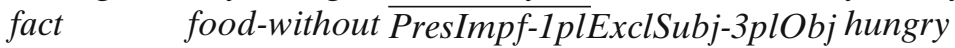

nyina.

sit.NPast

Isn't it obvious that we are waiting for them (here) hungry without any food? (Warlpiri Dictionary Project 1993)

On the present analysis, Evidential does not trigger head movement; it lacks the $\left[\mathrm{EPP}_{\text {Head }}\right]$ feature. In (52a), TopicP and FocusP are absent. T attracts Aspect; $\mathrm{C}$ attracts, raising $\mathrm{T}+$ Aspect to $\mathrm{C}$. Evidential does not attract. The clitics surface in $\mathrm{C}$, in second position, after the evidential. In (52b), miyiwangu 'without food' is focused. T, C, and Focus all attract in turn, resulting in the complex head Focus $+\mathrm{C}+\mathrm{T}+$ Aspect in the head of FocusP. Focus also attracts the focused phrase miyiwangu to the specifier of FocusP. This results in the clitics surfacing in Focus, in third position, after the evidential and the focused phrase. Notice that this account predicts without further ado that the complementizer and attached clitics cannot appear initially before an evidential. The head of EvidentialP does not attract the clitics. Thus, there is no possible derivation that would result in the complementizer and clitics being placed before the evidential.

On the proposed account, once the placement of the clitics is accounted for, the behaviour of the complementizers follows without additional stipulation. Recall that the complementizers are not clitics, but share the distribution of the clitics, with the exception that the complementizers may also appear initially. This fact was problematic for alternative analyses. On the present analysis, in all derivations, the complementizer, tense, and aspect surface as (part of) a single complex head, regardless of whether the complementizer is overtly pronounced or null. Therefore, the distribution of the pronounced complementizer and attached clitics is exactly that of the clitics without the pronounced complementizer. As discussed above, the difference in their distribution follows from the enclitic status of the clitics. If the clitics surface in an initial position, the derivation crashes due to the lack of a phonological host for the clitics ${ }^{39}$ whereas if a (pronounced) complementizer surfaces initially, the derivation converges unproblematically. This analysis of the placement of

\footnotetext{
${ }^{39}$ See Section 4.2 for a limited exception.
} 
the complementizers means, for example, that the derivations of (53a) and (53b) are identical in relevant respects to (52a) and (52b), respectively.

a. Kulanganta kapu-npa-ju yu-ngkarla. counterfact FutC-2sgSubj-1sgObj give-Irrealis I thought you would have given it to me (but you didn't).

b. Karinganta warnarrpi-rlangu-rlu fact brother.in.law-kinship.pair-Erg kapi-pala-nyanu jalangu-ju wajampa-ma-ni. FutC-3dualSubj-AnaphObj now-Top injured-VF-NPast My two brother-in-laws will fight each other now. (Warlpiri Dictionary Project 1993)

In sum, clitics are placed through syntactic head movement, triggered by the properties of high functional heads in the clause. This often has the effect of placing clitics in second position in the clause, but not uniformly.

Now let us consider a standard challenge for the head-movement approach to clitics: the appearance of a head rather than a phrase in initial position. In Warlpiri, there are two relevant constructions: verb-initial clauses, like (54a), and preverb-initial clauses, like (54b) with the preverb warrarda 'always'.

a. Wangka-mi-ka-lu Yurntumu-wardingki-patu. speak-NPast-PresImpf-3plSubj Yuendumu-habitant-Pl

The Yuendumu people are speaking. (Laughren 2002:[14])

b. Warrarda-ka-ju janka-mi karnta yalumpu. always-PresImpf-1sgObj burn-NPast woman that

That woman is always angry with me. (Warlpiri Dictionary Project 1993)

I begin the discussion of such constructions in this section, and complete the discussion in Section 4.2.

Recall from Section 3.1 that verb-initial clauses cannot be explained as a last-resort operation to provide a host for the clitics. Complementizers (and attached clitics) may follow the verb, despite the fact that they are not clitics, and may appear initially. An example is repeated below:

(55) (Kuja pali-ja-lku,) waarr-paka-rnu-lku

DeclC die-Past-then, many.times-hit-Past-then

kala-lu-nyanu nyanungu-rla-ju katu-mparra.

Past $\overline{C-3 p l S u b j-A n a p h O b j 3 s g-L o c-T o p \quad t o p-a l o n g . s i d e ~}$

(When he died,) they would beat themselves over him. (Warlpiri Dictionary Project 1993) 
Therefore, the verb-initial ordering must be achieved syntactically, not phonologically.

I argue that such constructions should be identified with the long head movement construction ${ }^{40}$ (Lema and Rivero 1990; Rivero 1991, 1994, 1998, 2000, 2003; Roberts 1993; Borsley et al. 1996, and references therein), and Scandinavian stylistic fronting (Platzack 1988; Maling 1990; Rögnvaldsson and Thráinsson 1990; Holmberg and Platzack 1995; Holmberg 2000, 2005, and references therein); see Holmberg (2005) for these constituting a single construction (also suggested in Fanselow 2002; Ackema and Čamdžić 2003; Poole and Burton-Roberts 2004, among others). The construction under the term long head movement is well attested for example in many Slavic languages, certain Romance languages, and Breton. Examples from Lema and Rivero (1990), involving movement of a participle (or an infinitive) across an auxiliary, follow.

(56) a. Bulgarian

Pročel sum knigata.

read(I) have book.the

I have read the book.

b. Czech

Představil jsem se mu.

introduced(I) have him myself

I have introduced myself to him.

c. 19th century European Portuguese

Seguir-te-ei por toda a parte.

follow-you-will(I) by all the part

I will follow you everywhere.

d. Old Spanish

Darte he un exemplo.

give.you(I) will an example

I will give you an example.

e. Rumanian

Spune mi va?

tell me will(he/she)

Will he/she tell me? (Lema and Rivero 1990:2)

\footnotetext{
${ }^{40}$ Note that at this point in the discussion we use the term "long head movement" as an established label for the construction, independent of any particular analysis.
} 
The construction under the label stylistic fronting is found for example in Icelandic, Faroese, and Old Scandinavian. Examples from Icelandic follow:

(57) a. Ef gengið er eftir Laugaveginum ...

if walked is along the-Laugavegur

If one walks along Laugavegur ... (Rögnvaldsson and Thráinsson 1990)

b. Fram hefur komið að fiskað hefur verið í leyfisleysi á chílensku forth has come that fished has been illegally in Chilean fiskisvæði.

fishing.zone

It has been revealed that illegal fishing has taken place in the Chilean fishing zone. (Holmberg 2005:1)

It is worth noting that several properties that seemed to distinguish the constructions have been counterexemplified. For example, long head movement was thought to be restricted to matrix clauses, until Embick and Izvorski (1994) illustrated embedded long head movement in Bulgarian:

Rasbrah če pročel beše knigata.
understood.1sg that read.PastPart be.Past3sg book.the

I understood that you had read the book.

Stylistic fronting is also found in embedded clauses, as seen in (57) above.

In addition, as expected if long head movement and stylistic fronting represent the same phenomenon, long head movement is not limited to clitic auxiliaries. ${ }^{41}$ Examples follow:

a. Serbo-Croatian

Pojeo bješe sve gljive. eaten be-Past all mushrooms

He has eaten all the mushrooms. (Ackema and Čamdžić 2003)

b. Bulgarian

Proeli bjaxa statijata.

read aux.pt.3pl.pl paper.the

They had read the paper. (Lambova 2002)

c. Breton

Lennet en deus Yann al levr. read 3sg.M has Yann the book

Yann has read the book. (Borsley et al. 1996)

\footnotetext{
${ }^{41}$ For auxiliaries that have both clitic and non-clitic forms, like sam versus jesam 'am' in SerboCroatian, the clitic form is used in the long head movement construction. In a Distributed Morphology framework, the clitic and non-clitic auxiliaries compete for insertion into the auxiliary head in a post-syntactic morphological component. The clitic forms must win the competition in this syntactic environment; we leave the morphological details aside.
} 
For further discussion of long head movement as stylistic fronting see Holmberg (2005) and the discussion below.

To equate verb-initial clauses in Warlpiri with this phenomenon is to suggest that suffixed lexical verbs in Warlpiri are participles. This is in accordance with the standard practice of referring to the clitic cluster in Warlpiri as an auxiliary, but the issue has not been directly addressed previously. Here we present several pieces of suggestive evidence that the verbal suffixes should be identified as participle morphology, rather than morphology realizing the features of $\mathrm{T}^{42}$ The evidence indicates that the verbal suffixes behave not as inflectional morphology related to a position high in the syntactic structure, but rather derivational morphology related to a position low in the syntactic structure.

First, the past suffix triggers a lexically restricted regressive $i \rightarrow u$ vowel harmony pattern from the suffix to the verbal root, while the language otherwise exhibits productive progressive $u \rightarrow i$ harmony from roots to suffixes and clitics (see Nash 1986; Harvey and Baker 2005, for details).

$$
\begin{array}{ll}
\text { kiji-rni } \quad \text { kiji-ka versus kuju-rnu } \\
\text { throw-NPast throw-Imper } & \text { throw-Past }
\end{array}
$$

Harvey and Baker (2005) explicitly analyse such forms as lexicalized. In a non-lexicalist framework, this translates into morphology merged close to the root (see Marantz 2001, for related discussion). In either case, this lexically restricted phonology suggests that the verb suffixes are not inflectional tense morphology, but rather derivational morphology.

Second, the non-past suffix appears inside nominalizing morphology in the gerund, which involves nominalization of the verb phrase (see Legate 2002, 2005). This indicates that the suffix originates within the the verb phrase, rather than in TP.

$$
\begin{aligned}
& \text { paka-rni-nja } \\
& \text { hit-NPast-Infin } \\
& \text { hitting }
\end{aligned}
$$

Third, the past suffix is closely related to a derivational morpheme: the agentive nominalizer in compounds, (62). The relationship between the past and the agentive nominalizer does not seem to be simply one of homophony, since the class-based allomorphy found for the past suffix is replicated in the

\footnotetext{
${ }^{42} \mathrm{An}$ anonymous reviewer notes that there is an interdependence between the aspectual clitics and the verb suffixes in that not all combinations are permitted; the reviewer suggests that this is explained through a local relationship between Aspect and T. On the present account, these restrictions may be accounted for by a local relationship between Aspect and the verb (or a low projection headed by the verb suffixes), if they are not semantic in origin. This issue is related to the source of the agreement morphemes; see the discussion in 4.1.
} 
agentive nominalization, with the exception that Class I collapses with Class III, (63).
a. marna-nga-rnu
grass-eat-Nom
grass eater
b. yarla-karla-ngu
yam-dig-Nom
yam digger (Nash 1986)

$\begin{array}{lccccc}\text { Verb Class } & \text { I } & \text { II } & \text { III } & \text { IV } & \text { V } \\ \text { Past } & \text {-ja } & -r n u & -n g u & -r n u & -n u \\ \text { Nominalizer } & \text {-ngu } & -r n u & -n g u & -r n u & -n u\end{array}$

This again suggests that the verbal suffixes are derivational morphology rather than inflectional morphology in TP.

Fourth, the present suffix appears inside the inceptive, which arguably heads a (light) verb phrase taking the verb phrase associated with the root as its complement; notice that the inceptive exhibits its own verbal suffixes: ${ }^{43}$

a. kiji-rni-nji-ni

throw-NPast-Incept-NPast

come/go and throw

b. kuju-rnu-nju-nu

throw-NPast-Incept-Past

came/went and threw

Thus, there is reason to believe that the verbal suffixes in Warlpiri are not inflectional morphology realizing $\mathrm{T}$, but rather participle morphology originating inside the verb phrase.

In addition, it is perhaps worth noting that the analysis of the lexical verbs as participles solves a technical problem with the verbal suffixes. Given that the tense head is standardly analysed as syntactically higher than the aspectual head, it has been difficult to explain how the tense head and verb could establish the needed relationship (be it checking, affix lowering, or verb raising) past the intervening aspect head. The participle analysis solves this problem by eliminating the relationship between the tense head and the

\footnotetext{
${ }^{43}$ The $r n i / r n u$ alternation in the nonpast morpheme in (64) is the result of vowel harmony, rather than being a nonpast/past distinction. This is clearly observed with a verb like nguna-(mi) 'lie', which has the zero nonpast with the inceptive in contrast with the ja past:
}

(i) nguna-nju-nu lie.NPast-Incept-Past came/went and lay

(ii) nguna-ja

lie-Past

lay 
verb. ${ }^{44}$ If this discussion is on the right track, then long head movement/stylistic fronting is a possible source for verb-initial clauses in Warlpiri.

Let us return to the construction and its analysis. An established property of long head movement/stylistic fronting is that it must target the highest element in the clause that is not a trace. For example, although a participle may be fronted, it cannot be fronted over negation, (65) ${ }^{45}$ and (66), or over a subject, (67) and (68).

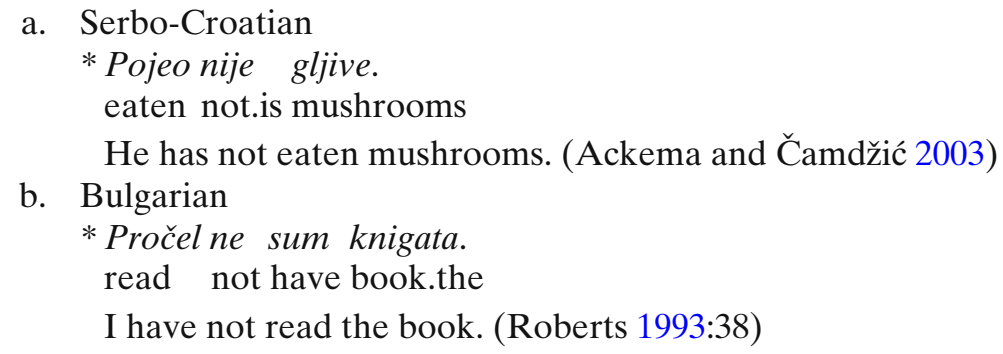

(66) Icelandic
a. pað fór að rigna, pegar búið var að borða.
Expl went to rain when finished was to eat
It began to rain when we had finished eating.
b. ... pegar ekki var búið að borða.
when not was finished to eat
c. *... pegar búið var ekki að borða.
when finished was not to eat (Maling 1990)

(67) Serbo-Croatian
a. *Pojeo Ivan je halapljivo gljive. eaten Ivan is greedily mushrooms
b. *Pojeo je Ivan halapljivo gljive. eaten is Ivan greedily mushrooms (Ackema and Čamdžić 2003)

\footnotetext{
${ }^{44} \mathrm{An}$ anonymous reviewer points out that there is interesting historical and comparative work to be done on the status of these verbal suffixes in Warlpiri and related languages. This may also help clarify the status of these suffixes as participles or inflected finite verbs.

${ }^{45}$ Note that nije in (65a) is a nonclitic auxiliary; there is no corresponding negative non-clitic form. See footnote 41 for related discussion.
} 
(68) Icelandic

a. Hver heldur pú að hafi stolið hjólinu? who think you that has stolen the bike Who do you think has stolen the bike?

b. Hver heldur pú að stolio hafi hjólinu? who think you that stolen has the.bike

c. Hvaða hjól heldur pú að hann hafi stolið? which bike think you that he has stolen Which bike do you think that he has stolen?

d. * Hvaða hjól heldur pú að stolið hann hafi? which bike think you that stolen he has (Jónsson 1991, cited in Holmberg 2005:4)

Nor can long head movement/stylistic fronting apply over higher adverbs. Note that this falls under the highest requirement, and does not indicate that the participle may not target a high position in the clause (contra Bošković 1995).

(69) Icelandic

a. ... sem sennilega er hægt að gera við. that probably is possible to fix PRT

b. *... sem hægt er sennilega að gera við. that possible is probably to fix PRT (Holmberg 2005:8)

(70) Serbo-Croatian

a. Jovan je nesumnjivo istukao Petra. Jovan is undoubtedly beaten Petar

Jovan undoubtedly beat Petar.

b. *Istukao je nesumnjivo Petra. beaten is undoubtedly Petar

He undoubtedly beat Petar. (Bošković 1995:248)

The fact that a participle cannot be fronted over PRO, indicates that the restriction is syntactic, not phonological, (71).

(71) Icelandic

a. Ég ætla að hafa lesið pessa bóká morgun.

I intend to have read this book tomorrow

b. * Ég ætla að lesið hafa pessa bóká morgun.

I intend to read have this book tomorrow

c. * Ég ætla lesið að hafa pessa bóká morgun.

I intend have to read this book tomorrow (Holmberg 2005:7)

A limited number of exceptions exist to the highest requirement, including weak subject pronouns (see Platzack 1988; Hrafnbjargarson 2004), and participle auxiliaries, (72) and (73). The intuition from Holmberg (2000) is that these elements are insufficiently contentful to undergo stylistic fronting. This strikes me as correct, but I will not dwell on the implementation, i.e. how to determine degree of content.

悬 Springer 
(72) Serbo-Croatian

a. Pojeo je sve gljive. eaten is all mushrooms

He has eaten all the mushrooms.

b. Pojeo je bio sve gljive eaten is been all mushrooms (Ackema and Čamdžić 2003:1-2)

(73) Icelandic

a. peir voru að tala um hvað hefði verið hægt. they were to talk about what had been possible

b. ... hvað hægt hefði verið. what possible had been (Holmberg 2005:9)

For Warlpiri, diagnosing the effect of the highest restriction is quite difficult, given the extent of word order freedom. One subcase is quite clear, however: it cannot apply over negation, as was recognized in Hale's original clitic placement rule, repeated below; (b) is the crucial clause.

I will assume that the auxiliary is basically initial in Walbiri and that it is moved into second position by the Aux-Insertion Rule. Furthermore, Aux-Insertion is $(a)$ obligatory if the portion of the auxiliary preceding the person markers is less than disyllabic (that is monosyllabic or phonologically null), $(b)$ blocked if the auxiliary is negative and is immediately followed by the verb, and $(c)$ optional otherwise. This insertion must be ordered in the grammar to follow all syntactic operations which have an effect on the ordering of nonauxiliary constituents. (Hale 1973:313)

This restriction against the verb preceding negation in Warlpiri is illustrated in (74).

$$
\begin{aligned}
& \text { a. Kula-ka-rna } \quad \text { ya-ni. } \\
& \text { NegC-PresImpf-1sgSubj go-NPast } \\
& \text { I'm not going. } \\
& \text { b. } \quad \text { Ya-ni kula-ka-rna } \quad \text { (ngaju). } \\
& \quad \text { go-NPast NegC-PresImpf-1sgSubj (I) } \\
& \quad \text { I'm not going. (Laughren 2002) }
\end{aligned}
$$

The analysis of long head movement/stylistic fronting is quite controversial. One class of analyses treats the construction as remnant movement of an XP projection of the verb consisting only of traces and the lexical verb. Indeed, this is the type of analysis proposed for the Warlpiri case in Laughren (2002). We do not adopt this type of approach here for two primary reasons.

First, this type of analysis does not provide an explanation of the highest restriction. It requires that everything except the participle have raised out of the 
verb phrase before the remnant movement applies - leaving the verb phrase the lowest XP in the projection, rather than the highest. Second, the construction does not typically alternate with unambiguously phrasal movement of the verb phrase. For many languages, this means that auxiliaries that allow long head movement do not allow fronting of the verb phrase:

(75) Bulgarian

*pročel knigata e.

read.PP book.the be.3sg.Pres

He has read the book.

(76) Rumanian

a. Spune mi va?

tell me will(he/she)

Will he/she tell me?

b. *Citi cartea Maria va. read book.the Maria will

Maria will read the book.

c. cf: Citi cartea nu am putut. read book.the not(I) have could

I have not been able to read the book. (Lema and Rivero 1990:9)

For Warlpiri, this means that unambiguous phrasal movement of the verb is uniformly ungrammatical. ${ }^{46}$ The object may not undergo phrasal movement with the verb:

a. *Wawirri nya-nyi-ka-rna.

kangaroo see-NPast-PresImpf-1sgSubj

I am looking at a kangaroo.

b. *Nya-nyi wawirri-ka-rna. see-NPast kangaroo-PresImpf-1sgSubj

I am looking at a kangaroo. (Hale et al. 1995: 1434)

The ungrammaticality of these constructions may be accounted for by overt object raising to a VP-external case licensing condition, as proposed in Laughren (2002). However, no other VP-internal material may move with the verb either - adverbs, prepositional phrases, or any other material; an example follows (Nash 1982):

$$
\begin{aligned}
& \text { *Yaruju-(rlu) paka-rnu-ju. } \\
& \text { quickly-(Erg) hit-Past-1sgObj } \\
& \text { He/she/it hit me quickly. }
\end{aligned}
$$

Further arguments against a verb-phrase fronting analysis of long head movement for the Slavic languages are established in the literature. For

\footnotetext{
${ }^{46}$ Note that Warlpiri does indeed have a verb phrase; see Legate $(2002,2003$ a) for discussion. 
example, unlike the long distance head movement construction, verb-phrase fronting in Serbo-Croatian can apply across negation:
Pojeo gljive
nije.
eaten mushrooms not.is

He did not eat mushrooms. (Ackema and Čamdžić 2003)

This difference in behaviour between long head movement and verb phrase movement indicates that long head movement should not be reduced to verb phrase movement. See inter alia Ackema and Čamdžić (2003), Caink (1999), Lema and Rivero (1990) for additional arguments against a phrasal movement analysis.

A second class of analyses proposes that the participle undergoes head movement through the functional projections of the clause with the auxiliary. This type of analysis cannot explain the fact that XP-level categories like the subject and high adverbs block fronting, see above. Nor can it explain fronting of XP-level categories (see Holmberg 2000, 2005).

Instead, I propose that long head movement/stylistic fronting is an example of pure EPP-driven movement, in the extended sense of Chomsky (2001) and subsequent, which may be checked either by a head or phrase. ${ }^{47} \mathrm{~A}$ high syntactic projection has an EPP feature uncoupled with any other contentful feature. The independence of this EPP feature explains the fact, discussed, for example, in Holmberg (2000), that the operation is not associated with any clear discourse interpretation (topic or focus). It also explains the unselectivity of elements that may check the feature, and the highest restriction. Due to the lack of coupled features, the identity of the host projection is difficult to determine, although, given the established interaction with subjects, it must belong to the left periphery above TP. I will refer to it simply as XP, pending further refinements.

Consider a concrete example from Warlpiri:

(80) Jaamalamala-karri-mi ka-lu open.wide-stand-NPast PresImpf-3plSubj that asleep-from kuja-ka-lu yakarra-pardi-mi manu yangka kurdu DeclC-PresImpf-3plSubj awake-rise-NPast and that child ka-lu jaamalamala-karri-mi jarda-lku.

PresImpf-3plSubj open.wide-stand-NPast asleep-now

People yawn when they wake up and babies yawn when sleepy. (Warlpiri Dictionary Project 1993)

Leaving aside the second conjunct, we have the verb 'yawn' (jaamalamalakarri-mi), consisting of a preverb combined with a light verb, followed by the

\footnotetext{
${ }^{47}$ For features that may be checked either by head movement or phrasal movement, see for example Legate (1996), Massam and Smallwood (1997), and especially Alexiadou and Anagnostopoulou (1998).
} 
auxiliary, followed by a 'when' clause. ${ }^{48}$ There is no overt subject, the identity of the external argument recoverable from the third plural subject agreement. I assume that the auxiliary cluster is in $\mathrm{T}$ (or perhaps a null $\mathrm{C}$ ), given the lack of an overt evidential, topic, or focus in the clause. At the point of merger of the $\mathrm{X}$ head, the subject pro must be below the verb. This ordering is of course well attested for overt subjects in Warlpiri. The $\mathrm{X}$ head is merged, with its EPP feature. It searches down the tree and attracts the first element it finds, ignoring the clitics and auxiliaries (see above). This is the verb 'yawn', which it attracts. Since this is a head, it lands in the head of X. Movement of XP categories is assumedly also possible in Warlpiri, however this will simply yield an XP before the clitics, an unremarkable instance of clitic second.

This analysis thus provides a syntactic explanation for clauses in which the verb precedes the clitic cluster. There is reason to believe, though, that not all second word phenomena fall under this analysis. In the following section, I consider verb focus and preverb split constructions, which reveal the role of morphology in second position clitic placement in Warlpiri.

\section{2 ... Plus morphology}

In this section we consider two first word phenomena that cannot be explained as a subcase of the pure EPP-driven movement discussed in the previous section: verb focus and preverb splitting. Let us begin with verb focus; recall that this cannot be explained as purely EPP-driven movement since pure EPPdriven movement lacks a clear discourse function. An example of verb focus is repeated below.
a. Nyarrpa-jarri-mi ka-lu Yurntumu-wardingki-patu? how-Incho-NPast PresImpf Yuendumu-habitant-Pl What are the Yuendumu people doing?
b. Wangka-mi ka-lu Yurntumu-wardingki-patu. speak-NPast PresImpf-3plSubj Yuendumu-habitant-Pl
The Yuendumu people are speaking. (Laughren 2002)

The default assumption is that such constructions operate identically to other focus constructions. The $\left[\mathrm{EPP}_{\text {Head }}\right]$ feature of Focus attracts $\mathrm{C}$. In addition, the [Focus] feature attracts; the verb is found as the highest element bearing this

\footnotetext{
${ }^{48}$ A perhaps more natural translation of yangka here would be 'like': 'People yawn, like when they wake up from sleep, or like babies yawn when sleepy.
} 
feature, and the verb undergoes (long) head movement to adjoin to Focus. ${ }^{49}$ The following structure results:

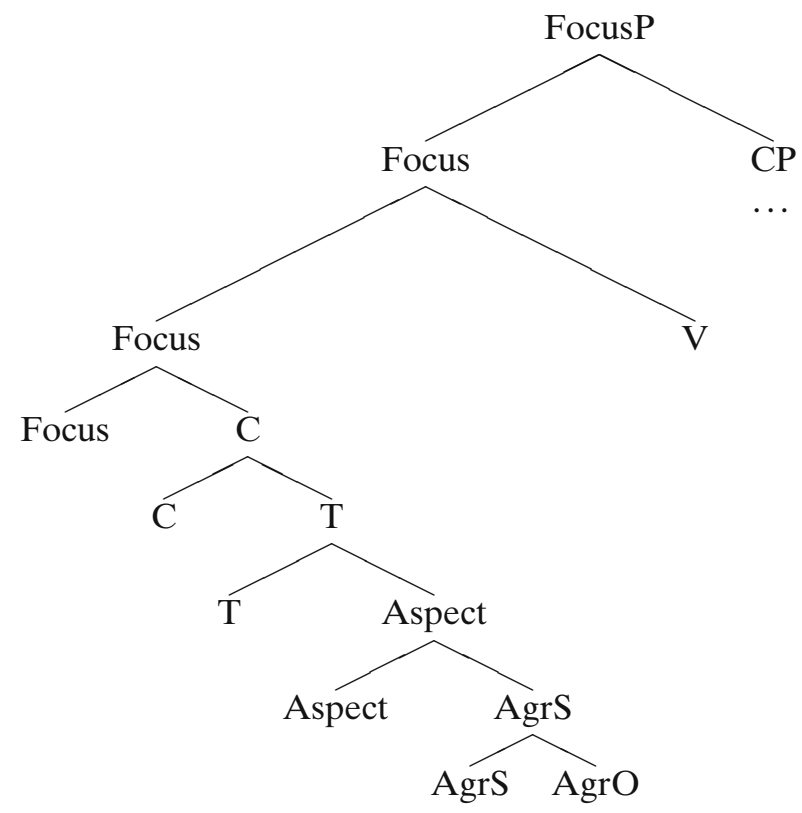

This is a straightforward application of the feature attraction mechanism to verbal focus, and perhaps can be viewed as a variant of the analysis developed in Roberts 1993, which extends Relativized Minimality (Rizzi 1990) to heads. ${ }^{50}$

\footnotetext{
${ }^{49}$ An anonymous reviewer asks how to prevent a phrasal element from occupying the specifier of FocusP while the verb occupies the head of FocusP. Warlpiri does not allow multiple foci in a single clause, thus the [Focus] feature only attracts once, resulting in either XP movement or (long) head movement, but not both. See related arguments in the literature for features that may be checked either by head movement or phrasal movement, for example Legate (1996), Massam and Smallwood (1997), Alexiadou and Anagnostopoulou (1998).

${ }^{50}$ Note that unlike Roberts $(1991,1993)$, we do not adopt excorporation. As noted in Iatridou (1994), excorporation would make restraining long head movement difficult, and may eliminate the need for long head movement.
} 
The linearization mechanism, repeated in (83), will yield clitic + verb order for this structure. ${ }^{51}$

$$
\overbrace{\mathrm{X} Y \mathrm{Y}}^{\mathrm{X}} \rightarrow \mathrm{X} * \mathrm{Y}
$$

Before discussing the mechanism that yields verb + clitic order, I consider the second first word construction: preverb-initial clauses. ${ }^{52}$

Recall that the clitics may separate the preverb from the verb; an example follows, with the preverb yarda 'again':

$$
\begin{aligned}
& \text { Yarda-ka-lu } \\
& \text { again-PresImpf-3plSubj go-NPast }
\end{aligned}
$$

They are going again. (Laughren 2002)

A description of Warlpiri preverbs is presented in Nash (1982). Nash observes that the preverbs classify into distinct types, based on the closeness of the relationship with the verb root. One type is the adverbial/quantificational and dative adjunct preverbs. These combine freely with any verb, are semantically

\footnotetext{
${ }^{51}$ It is not clear whether Warlpiri also has standard verb raising. If so, the following structure would result:
}

(i)

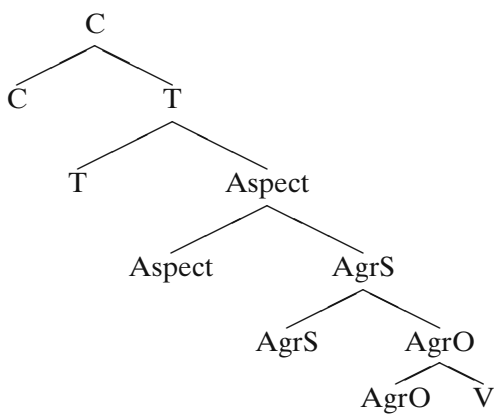

This would also yield clitics + verb ordering after linearization. Given the morphological operation proposed below, this would be an additional source for verb-initial and preverb-initial clauses.

${ }^{52}$ See Carnie et al. (2000), Adger (2000) for approaches to a related construction in Old Irish. Thank you to anonymous reviewers for comments leading to improvements in this section. 
transparent, and occur outermost in a sequence of preverbs. Examples are yarda in (84), jurnta 'away', and warrarda 'always': ${ }^{\text {. }}$

a. Kulu-parnta-ku kala-rnalu-jana

anger-having-Dat PastC-1plExclSubj-3plObj

jurnta-wuruly-parnka-ja.

away-escape-run-Past

We ran away from those angry people.

b. Jurnta-ka-rla ma-ni yapa-kari-ki.

away-PresImpf-3DatObj get-NPast person-other-Dat

He takes it away from another person. (Warlpiri Dictionary Project 1993)

a. Malamarri kala-lu nyina-ja jarlu-patu skilled.hunter Past $\overline{C-3 p l S u b j ~ b e-P a s t ~ o l d . m a n-P a u c}$ kuja-lpa-lu kuyu warrarda pu-ngu.

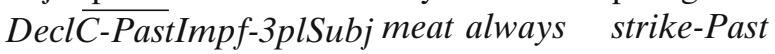

'The old people used to be expert hunters who always caught game.'

b. Warrarda-ka-ju janka-mi karnta yalumpu. always-PresImp $f-1 s g O b j$ burn-NPast woman that

That woman is always angry with me. (Warlpiri Dictionary Project 1993)

As illustrated in (84), (85b), and (86b), adverbial/quantificational and dative adjunct preverbs participate in the preverb split construction. However, they

\footnotetext{
${ }^{53}$ Adverbial preverbs are distinct from non-preverb adverbs like yaruju 'quickly': the preverb+verb combination may appear as a unit before the second position clitics (i)-(ii), whereas adverb+verb combinations may not, (iii); adverbs agree in case with the subject of the clause, (iv), whereas preverbs do not, (ii), (v), (Nash 1982).
}

(i) Yarda ya-nu-lpa.

again go-Past-PastImpf

$\mathrm{He} / \mathrm{she} /$ it was going again.

(ii) Warrarda nya-nyi-ka-ju. always look-NPast-PresImpf-1sgObj

He keeps looking at me.

(iii) *Yaruju-(rlu) paka-rnu-ju. quickly-(Erg) hit-Past-1 $\overline{s g} \mathrm{Obj}$

$\mathrm{He} / \mathrm{she} /$ it hit me quickly.

(iv) Yaruju-rlu-ju paka-rnu. quickly-Erg-1 sgObj hit-Past

$\mathrm{He} / \mathrm{she} /$ it hit me quickly.

(v) Jinta-kari-rli-ji yarda paka-rnu kakarda.

one-other-Erg-Top again hit-Past nape.of.neck

The other one struck him once again on the back of the neck. (Warlpiri Dictionary Project 1993) 
also show syntactic independence from the verb in that they may appear following the verb, and may be separated from the verb by clausal material (Nash 1982). ${ }^{54}$ This is illustrated below for jurnta 'away', and warrarda 'always':

Yunta-rla muku kuju-rnu jurnta karnta-ku-ju.

windbreak-3DatObjall throw-Past away woman-Dat-Top

He threw the windbreak off from the woman. (Warlpiri Dictionary Project 1993)

a. Wurdungu-jala-lpa-rnalu nyina-ja, pama-jangka-ju quiet-certainly-PastImpf-1plExclSubj sit-Past alcohol-from-Top lirra wiri-kirli-lpa wangka-ja warrarda. mouth big-having-PastImpf speak-Past always

We were quiet but the drunken loud mouth kept on and on talking.

b. Warrarda-ka-jana panu-kari paka-rni kulu-ngku. always-PresImpf-3plObj many-other hit-Past anger-Erg He is always hitting others aggressively. (Warlpiri Dictionary Project 1993)

Thus, we need not say anything special about clitic placement for these preverbs: they may be separated from the verb in the syntax, and may be separated from the verb by the clitic cluster.

The other type of preverb is the most interesting from our perspective, those Nash calls semi-productive. ${ }^{55}$ These occur inside adverbial and dative adjunct

\footnotetext{
${ }^{54}$ Legate, in preparation, analyses the contrasting behaviour of the adverbial/quantificational preverbs versus the semi-productive preverbs in terms of merge position: the adverbial/quantificational are merged above $v \mathrm{P}$, whereas the semi-productive are merged low inside the verb phrase. See Svenonius (2004) for a similar distinction among Slavic prefixes.

${ }^{55}$ Nash includes a third type of preverb, which he calls "lexical". These he suggests do not participate in the preverb split construction. However, subsequent data have revealed that at least a subset of these may indeed participate in the preverb split construction, (i) alternating with (ii):
}

(i) Yirri-kiji-rni-ka-lu-jana maliki kulu-parnta, marlu-ku, Preverb-throw-NPast-PresImpf-3plSubj-3plObj dog anger-having kangaroo-Dat yankirri-ki manu yapa-ku. emu-Dat and person-Dat

They sick aggressive dogs onto kangaroos, emus, and people. (Warlpiri Dictionary Project 1993)

(ii) Yirri-ka-lu-jana kiji-rni $\ldots$

Preverb-PresImpf-3plSubj-3plObj throw-NPast

Further research is needed to determine any limits on preverb splitting. For example, my consultants do not accept splitting in the following idiomatic example:

(iii) *Pirri-ka mati-rni milpa.

scattered-PresImpf travel.in.line-NPast eye

His eyes are popping out.

On the current theory, preverbs that do not allow splitting undergo obligatory (string vacuous) local dislocation with the verb. We do not consider such preverbs further here. Thank you to Mary Laughren for discussion. 
preverbs. They vary in productivity, some combining with a few specific roots while others combine with any semantically appropriate verb root. They may give rise to unpredictable and idiomatic interpretations. Examples are pirri 'scattered' in (89), and walyi 'spilt' in (90).

a. Pirri-kiji-rni ngula-ji yangka kuja-ka scattered-throw-NPast that-Top like DeclC-PresImpf yapa-ngku miyi, manu kuyu kiji-rni kujapurda-kujapurda, person-Erg food and meat throw-NPast towards-towards yangka kuja-ka-lu pirri-nguna-mi manu like DeclC-PresImpf-3pl scattered-lie-NPast and pularra-nguna miyi manu kuyu kiji-rninja-warnu. scattered-lie food and meat throw-Infin-after

Pirrikijirni is like when a person tosses food and meat here and there, so that the food lies scattered after being thrown.

b. Pirri-parnka-ja-lu,$\quad$ ngula-ju- $\underline{\mathrm{u}}$, jinta-kari-jinta-kari scattered-run-Past-3plSubj that-Top-3plSubj one-other-one-other jarnku-parnka-ja. separately-run-Past They ran and scattered. That is each one ran off on his own.

c. Milpa-lku pirri-matu-rnu. eye-then scattered-travel.in.line-Past Then his eyes popped out. (Warlpiri Dictionary Project 1993)

(90) a. Purru-rla walyi-karli-ja. milk-3DatObj spilt-flow-Past The milk spilt over from it.

b. Nyiya-npa walyi-ma-nu nyampu-ju? what-2sgSubj spilt-Cause-Past here-Top What have you split here?

c. Walyi-kiji-rni, ngula-ji yangka kuja-ka karnta-ngku spilt-throw-NPast that-Top like DeclC-PresImpf woman-Erg ngapa kartaku-ngurlu kiji-rni walya-kurra. water billycan-from throw-NPast ground-All Walyi-kijirni is like when a woman throws water out from a billycan onto the ground. (Warlpiri Dictionary Project 1993)

Such preverbs may not be separated from the verb by any phrasal material; however, they may be separated from the verb by the clitic cluster (Nash 1982), as illustrated here with yitaki 'tracked' and pirri 'scattered':

a. Yitaki-rra-jana ma-nu parnman-kurlangu-rlangu tracked-Thither-3plObj get-Past mother.in.law-having-kinship.pair kuja-lpa-lu ya-nu. Decl C-PastImpf-3plSubj go-Past

He went off tracking his mother-in-law and his wives, following where they had gone. (Warlpiri Dictionary Project 1993) 
b. Pirri-ka-lu nguna-mi miyi manu kuyu scattered-PresImpf-3plSubj lie-NPast food and meat kiji-rninja-warnu.

throw-Infin-after

The food and meat lie scattered after being thrown.

Thus, we have a clear first word effect in Warlpiri: semi-productive preverbs may be separated from the verb by the clitics but by no other phrasal material. ${ }^{56}$

Recall that in Section 3.1 above, we argued that this is a morphological rather than phonological first word effect: the clitics must be positioned between the preverb and the verb in the morphology, partly in order to capture the lexically-dependent choice of augment found on consonant-final preverbs:

a. jaaly(pa) 'whispering', jamparl(pa) 'chewing', kanginy(pa)

'ignorant', karlirr(pa) 'swerving', paarr(pa) 'into the air', $\operatorname{tiirl}(\mathrm{pa})$ 'split', ...

b. liirl(ki) 'white', miril(ki) 'shine', larlarl(ki) 'up high', ...

Preverb-initial clauses involving semi-productive preverbs crucially differ from verb-initial clauses in that the complementizer may not follow the preverb. Only clitics without a complementizer host may separate the semiproductive preverbs from the associated verb. Thus, the preverb-initial clauses are indicative of a repair mechanism in a way that the verb-initial clauses discussed in the previous section are not.

Consider how focus movement will affect preverbs. Given that the preverbs cannot be syntactically separated from the associated verb, the entire complex head including the verb and preverb will be moved. This will result in the preverb, verb, and clitics occupying a single complex head. Such a derivation was discussed above for the case of focus movement of the verb, and illustrated (82). This is repeated below with the addition of the preverb, in (93). ${ }^{57}$

\footnotetext{
${ }^{56}$ This observation argues against adopting the approach to the preverb split construction proposed in Laughren (2002) as a general account of the phenomenon. Simplifying somewhat, Laughren claims that the preverbs head a projection dominating the verb phrase; clauses in which the verb appears in a high position result from phrasal movement of this projection. In the preverb split construction, the projection headed by the preverb undergoes phrasal movement to a projection immediately below the clitics. The preverb then moves out of this specifier to the specifier preceding the clitics. The movement of the preverb may violate the left branch condition, and the necessity for phrasal movement of the preverb+verb to the position below the clitics only in this construction is not explained. Most importantly, the semi-productive prefixes indicate that this type of approach cannot be the full explanation of the preverb split construction; note that that work focuses on the adverbial/quantificational preverbs. The semi-productive preverbs are syntactically immobile and yet participate in the construction; thus the analysis cannot require syntactic movement of the preverb.

${ }^{57}$ Note that a specific ordering principle applies to VP-internal head adjunction, including at least the verb-preverb combination:
}

$$
\overbrace{\mathrm{X}}^{\mathrm{X}} \rightarrow \mathrm{Y} * \mathrm{X}
$$




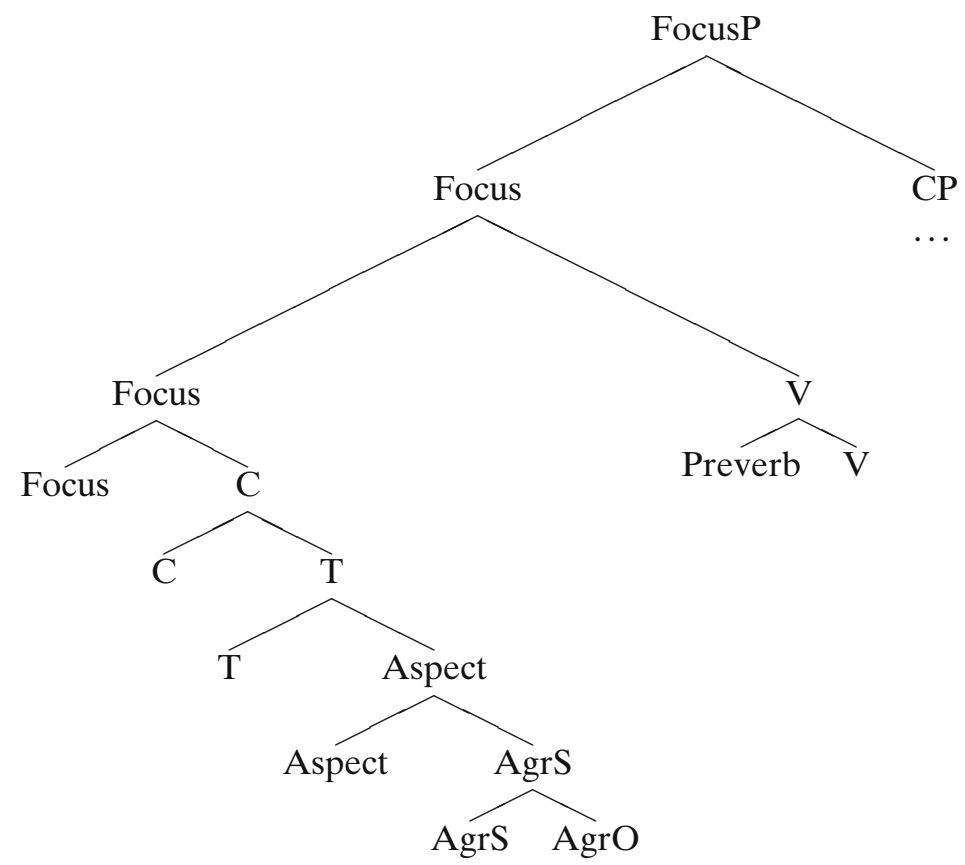

Again the linearization algorithm yields clitic-preverb-verb order. If $\mathrm{C}$ is overt, the clitics will suffix to $\mathrm{C}$. If $\mathrm{C}$ is null, the clitics will suffix to a preceding phonological word. However, if $\mathrm{C}$ is null and no preceding phonologically overt material is present, the clitics lack a host.

I propose a limited repair operation, applicable in both verb focus and preverb split constructions. I refer to this operation as AFFIX, which suffixes the clitics to a following phonological word within the same complex head:

\section{(94) AFFIX}

$$
\left[x^{\theta} \mathrm{Y} * \mathrm{Z} \ldots\right] \rightarrow\left[x_{X^{\theta}} \mathrm{Z}+\mathrm{Y} \ldots\right]
$$

AFFIX is a subtype of Morphological Merger (Marantz 1984), akin to local dislocation of subwords in the terminology of Embick and Noyer (2001), and perhaps prosodic inversion (Halpern 1995) coupled with sensitivity to syntactic structure. It applies only when triggered by the suffixal requirements of $Y$ (or conversely, the prefixal requirements of $\mathrm{Z}$ ). For the case of an affixal $\mathrm{Y}$, such an operation is standardly assumed without comment as part of the lexical insertion of an affix. The affix is inverted with the stem as necessary to satisfy its prefixal/suffixal requirements. For the case of a clitic Y, however, the separation between the lexical insertion and subsequent application of AFFIX becomes clear: after lexical insertion the clitic attempts to adjoin to ("lean on") preceding phonologically overt material. Only if this attempt fails may AFFIX apply. 
The application of AFFIX in the preverb split construction case is illustrated in (95) (null heads ignored). When no preceding material is present to host the clitics, the suffixal requirement of Aspect triggers application of AFFIX. This adjoins Aspect (and adjoined agreement clitics) to the preverb:

$$
\begin{aligned}
& {\left[\text { Focus }^{\theta} \text { Aspect }+ \text { AgrS }+ \text { AgrO } * \text { Preverb } * \mathrm{~V}\right] \rightarrow\left[\text { Focus }^{\theta} \text { Preverb }+ \text { Aspect }+\right.} \\
& \text { AgrS }+ \text { AgrO } * \mathrm{~V}]
\end{aligned}
$$

In this structure, the preverb forms a phonological word independent from the verb. If the preverb is consonant final, this triggers a morphological readjustment rule adding the $\mathrm{CV}$ augment to the preverb. The preverb then combines with the verb only at the level of the phonological phrase.

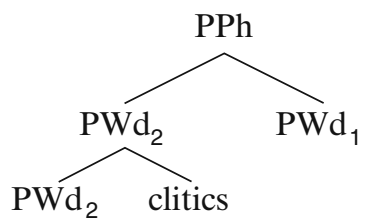

The requirement that AFFIX be triggered by the suffixal nature of the clitics explains the fact that overt complementizers may not intervene between the preverb and verb in the preverb split construction. The suffixal requirement of the clitics is satisfied by the complementizer, and thus AFFIX is not triggered. It also explains the ungrammaticality of the preverb split construction when a potential host precedes the clitics in the clause..$^{58}$

The derivation also explains the requirement that the verb immediately follow the clitics in the preverb split construction, even though the verb does not form a phonological word with the preverb. The preverb is syntactically head-adjoined to the verb, and is separated from it only morphologically.

The proposed analysis also explains a generalization noted in Laughren (2002): in constructions with multiple preverbs, the clitics may only adjoin to the outermost preverb: ${ }^{59}$
a. Pina-rna wuruly-parnka-ja ngurra-kurra. back-1sgSubj concealed-run-Past home-All I ran away back home.
b. *Pina wuruly(pa)-rna parnka-ja ngurra-kurra. back concealed-1sgSubj run-Past home-All I ran away back home.

\footnotetext{
${ }^{58}$ Thank you to an anonymous reviewer for raising this point.

${ }^{59}$ Thank you to an anonymous reviewer for these examples.

Springer
} 
The operation of AFFIX applied to this example correctly produces only affixation of the clitics to the outermost preverb:

$$
\left[X^{\Gamma} \text { AgrS } * \text { Preverb } * \text { Preverb } * V\right] \rightarrow\left[{ }_{X^{\Gamma}} \text { Preverb }+ \text { AgrS } * \text { Preverb } * V\right]
$$

To conclude this section, we have argued for a small number of operations that combine to produce the full range of clitic placement possibilities in Warlpiri. The Aspect and $\mathrm{C}$ heads undergo syntactic head movement, based on the presence of [ $\left.\mathrm{EPP}_{\text {Head }}\right]$ features on high functional heads within the clause. This operation derives several properties of clitic placement: the dependence on $\mathrm{C}$, the non-uniqueness of the syntactic position, and the placement later than second in clauses with an evidential marker-the evidential head lacks the $\left[\mathrm{EPP}_{\text {Head }}\right]$ feature. A purely EPP-driven movement, exemplified in other languages under the label "long head movement" and "stylistic fronting", attracts the highest element in the clause that is not a trace, skipping over low content items like auxiliary verbs and weak pronouns. When the highest element in the clause is the verb, it is attracted, yielding verb-initial order. Focus movement also can apply to verbs (and any adjoined preverbs), yielding long head movement. This derivation will yield clitic-verb order in the default case. However, if the clitics would then be left initial without a host, AFFIX applies, a limited type of Morphological Merger operation that adjoins a suffix to following material within the same complex head. AFFIX is motivated independently for affixation within a head, and correctly derives the properties of the preverb split construction in which the clitics intervene between a preverb and its associated verb.

\section{Conclusion}

This paper has addressed two issues: (i) what the properties of Warlpiri clitic placement are; and (ii) how these properties should be analysed. Regarding the first issue, we have found a number of interesting properties of Warlpiri clitics that must be accounted for under any analysis:

- the clitics do not occupy a uniform syntactic position

- the clitics can never interrupt syntactically intact DPs/PPs

- the clitics can interrupt preverb+verb units that cannot be separated syntactically (in addition to those units that can be separated syntactically)

- the complementizers are not clitics, and may appear initially

- otherwise the complementizers closely share the positioning possibilities of the clitics

- the position of the complementizers has interpretive consequences

- the placement in second position is not uniformly observed-neither syntactically nor phonologically

- the placement of the clitics exhibits a degree of optionality

Regarding the second issue, we have developed an analysis whereby primary clitic placement is achieved through Attract-driven syntactic headmovement to high functional projections. The surface position of the clitics is 
non-unique, dependent on the functional projections present in the clause. In addition, limited morphological reordering was posited, through an operation affixing morphological terminals to a host within the same complex head. This provided a simple explanation for the problematic preverb-initial clauses.

Acknowledgements Thank you to Steve Anderson, Molly Diesing, Marcel den Dikken, Mary Laughren, Charles Yang, Draga Zec, the audiences at the linguistic colloquia at Cornell University (2004) and the University of Delaware (2004), and three NLLT reviewers for comments and discussion. Thank you to my Warlpiri consultants Carol Napangardi Gallagagr, Helen Napurrula Morton, Nancy Napurrula Oldfield, Bess Nungarrayi Price, Teresa Napurrula Ross, Christine Nungarrayi Spencer, Ena Napaljarri Spencer, Ruth Napaljarri Stewart. Glosses for examples from the Warlpiri Dictionary (Warlpiri Dictionary Project 1993) and for examples from the Survey of Warlpiri Grammar (Granites et al. 1976) are my own. To aid the reader, glosses in examples from other sources have been regularized.

\section{References}

Ackema, P., \& Čamdžić, A. (2003). LF complex predicate formation: The case of participle fronting in Serbo-Croatian. UCL Working Papers in Linguistics, 15, 131-175.

Adger, D. (2000). First position and the syntax/prosody interface: old Irish preverbs. In Proceedings of WCCFL (Vol. 19, pp. 1-14). Somerville, MA: Cascadila Press.

Alexiadou, A., \& Anagnostopoulou, E. (1998). Parametrizing AGR: Word-order, V-movement and EPP checking. Natural Language and Linguistic Theory, 16, 491-539.

Anderson, S. R. (1993). Wackernagel's revenge: Clitics, morphology, and the syntax of second position. Language, 69, 68-98.

Anderson, S. R. (1995). Rules and constraints in describing the morphology of phrases. In CLS Parasession volume on Clitics (Vol. 31, pp. 15-31). Chicago Linguistic Society.

Anderson, S. R. (1996). How to put your clitics in their place. The Linguistic Review, 13, 165-191.

Anderson, S. R. (2000). Towards an optimal account of second position phenomena. In J. Dekkers, et al. (Eds.), Optimality theory: syntax, phonology and acquisition (pp. 302-333). Cambridge: Oxford University Press.

Anderson, S. R. (2004). Subject clitics and verb-second in Surmiran Rumantsch. MIT Working Papers in Linguistics, 47, 1-22.

Anderson, S. R. (2005). Aspects of the theory of clitics. Oxford: Oxford University Press.

Anttila, A. (2002). Variation and phonological theory. In J. Chambers, P. Trudgill, \& N. SchillingEstes (Eds.), Handbook of language variation and change (pp. 206-243). Oxford: Blackwell.

Austin, P., \& Bresnan, J. (1996). Non-configurationality in Australian aboriginal languages. Natural Language and Linguistic Theory, 14.2, 215-268.

Berendsen, E. (1986). The phonology of cliticization. Dordrecht: Foris.

Berry, L. M. (1999). Alignment and adjacency in optimality theory: Evidence from Warlpiri and Arrernte. Doctoral dissertation, Department of Linguistics, University of Sydney.

Billings, L. A. (2002). Phrasal clitics. Journal of Slavic Linguistics, 10.1, 53-104.

Bittner, M., \& Hale, K. (1995). Remarks on definiteness in Warlpiri. In E. Bach, E. Jelinek, A. Kratzer, \& B. Partee (Eds.), Quantification in natural language (pp. 81-106). Dordrecht: Kluwer.

Bobaljik, J. D. (2002). A-chains at the PF-interface: Copies and "Covert" movement. Natural Language and Linguistic Theory, 20.2, 197-267.

Boersma, P. (1998). Functional phonology: Formalizing the interactions between articulatory and perceptual drives. Doctoral dissertation, University of Amsterdam.

Borsley, R. D., Rivero, M. L., \& Stephens, J. (1996). Long head movement in Breton. In R. Borsley \& I. Roberts (Eds.), The Syntax of the celtic languages (pp. 53-74). Cambridge: Cambridge University Press

Bošković, Ž. (1995). Participle movement and second position cliticization in Serbo-Croatian. Lingua, 96, 245-266. 
Bošković, Ž. (2001). On the Nature of the Syntax-Phonology Interface. Elsevier.

Butcher, A., \& Harrington, J. (2003a). An Acoustic and articulatory analysis of focus and the word/morpheme boundary distinction in Warlpiri. In Proceedings of the 6th international seminar on speech production (pp.19-24). Macquarie Centre for Cognitive Science, Macquarie University.

Butcher, A., \& Harrington, J. (2003b). An instrumental analysis of focus and juncture in Warlpiri. In M. J. Solé, D. Recasens, \& J. Romero (Eds.), Proceedings of the 15th international congress of the phonetic sciences (pp. 321-324). Barcelona: Universitat Autónoma de Barcelona.

Caink, A. D. (1999). Against long head movement. In M. Dimitrova-Vulchanova \& L. Hellan (Eds.), Topics in south slavic syntax and semantics (pp. 91-123). Amsterdam: John Benjamins.

Carnie, A., Harley, H., \& Pyatt. E. (2000). VSO order as raising out of the IP? Some evidence from old Irish. In A. Carnie \& E. Guilfoyle (Eds.), The syntax of verb-initial languages (pp. 39-60). Cambridge: Cambridge University Press.

Chomsky, N. (1993). A minimalist program for linguistic theory. In K. Hale \& S. J. Keyser (Eds.), The view from building 20 (pp. 1-52). Cambridge, MA: MIT Press.

Chomsky, N. (1995). The minimalist program. Cambridge, Mass.: MIT Press.

Chomsky, N. (2001). Derivation by phase. In M. Kenstowicz (Ed.), Ken Hale: A life in language, (pp. 1-52). Cambridge, MA: MIT Press.

Cinque, G. (1999). Adverbs and functional heads: A cross-linguistic perspective. Oxford: Oxford University Press.

Embick, D. (1997). Voice and the interfaces of syntax. Doctoral dissertation, University of Pennsylvania.

Embick, D. (2000). Features, syntax and categories in the latin perfect. Linguistic Inquiry, 31(2), 185-230.

Embick, D., \& Izvorski, R. (1994). On long head movement. In J. M. Fuller, H. Han, \& D. Parkinson (Eds.), Proceedings of ESCOL (pp. 104-115). Somerville, MA: Cascadilla Press.

Embick, D., \& Noyer, R. (1999). Locality in post-syntactic operations. In MITWPL 34: Papers on morphology and syntax, cycle two (pp. 265-317). Cambridge, MA: MITWPL.

Embick, D., \& Noyer, R. (2001). Movement operations after syntax. Linguistic Inquiry, 32(4), 555-595.

Fanselow, G. (2002). Münchhausen-style head movement and the analysis of verb second. In A. Mahajan (Ed.), Proceedings of the workshop on head movement (pp. 40-76). Los Angeles: UCLA Linguistics Department.

Franks, S. (1997). South slavic clitic placement is still syntactic. In Proceedings of the 21st annual penn linguistics Colloquium (pp. 111-126).

Franks, S. (1998). Clitics in slavic. Paper presented at the comparative slavic morphosyntax workshop. Indiana University.

Franks, S., \& Progovac, L. (1994). On the placement of Serbo-Croatian clitics. Indiana Linguistics Studies, 7, 69-78.

Granites, R. J., Hale, K. L., \& Odling-Smee, D. (1976). Survey of Warlpiri Grammar. MIT ms.

Groat, E., \& O'Neil, J. (1996). Spell-out at the LF interface: Achieving a unified syntactic computational system in the minimalist framework. In W. Abraham, S. D. Epstein, H. Thráinsson, \& J.-W. Zwart (Eds.), Minimal ideas (pp. 113-139). Amsterdam/Philadelphia: John Benjamins.

Hale, K. (1960). Wal.piRi field notes. Available from the Australian Institute of Aboriginal and Torres Strait Islander Studies Library.

Hale, K. (1966). Wal.piRi field notes. Available from the Australian Institute of Aboriginal and Torres Strait Islander Studies Library.

Hale, K. (1973). Person marking in Walbiri. In S. R. Anderson \& P. Kiparsky (Eds.), A festschrift for Morris Halle (pp. 308-344). New York: Holt, Rinehart \& Winston, Inc.

Hale, K. (1976). Lessons in Warlpiri I-VIII. MIT ms.

Hale, K. (1983). Warlpiri and the grammar of non-configurational languages. Natural Language and Linguistic Theory, 1.1, 5-47.

Hale, K., Laughren, M., \& Simpson, J. (1995). Warlpiri syntax. In J. Jacobs, A. von Stechow, W. Sternefeld, \& T. Vennemann (Eds.), Syntax. Ein internationales Handbuch zeitgenössischer Forschung an international handbook of contemporary research (pp. 1430-51). Berlin New York: Walter de Gruyter. 
Halle, M. (1997). Distributed morphology: Impoverishment and fission. In B. Bruening, Y. Kang \& M. McGinnis (Eds.), PF: Papers at the interface. MIT working papers in linguistics (Vol. 30, pp. 425-449).

Halpern, A. (1995). On the placement and morphology of clitics. Stanford, CA: CSLI Publications.

Harvey, M., \& Baker, B. (2005). Vowel harmony, directionality and morpheme structure constraints in Warlpiri. Lingua, 115, 1457-1474.

Holmberg, A. (2000). Scandinavian stylistic fronting: How any category can become an expletive. Linguistic Inquiry, 31, 445-484.

Holmberg, A. (2005). Stylistic fronting. In M. Everaert \& H. van Riemsdijk (Eds.), The blackwell companion to syntax IV (pp. 530-563). Oxford: Blackwell.

Holmberg, A., \& Platzack, C. (1995). The role of inflection in scandinavian syntax. Oxford: Oxford University Press.

Hrafnbjargarson, G. H. (2004). Stylistic fronting. Studia Linguistica, 58.2, 88-134.

Iatridou, S. (1994). Comments on the paper by Roberts. In D. Lightfoot \& N. Hornstein (Eds.), Verb movement (pp. 243-260). Cambridge, UK: Cambridge University Press.

Inkelas, S. (1989). Prosodic constituency in the Lexicon. Doctoral dissertation. Stanford University.

Jelinek, E. (1984). Empty categories, case, and configurationality. Natural Language and Linguistic Theory, 2, 39-76.

Jónsson, J. G. (1991). Stylistic fronting in Icelandic. Working Papers in Scandinavian Syntax, 48, $1-43$.

Kager, R. (1995). Generalized alignment and morphological parsing. ROA \#36-1094.

King, T. H. (1996). Slavic clitics, long head movement, and prosodic inversion. Journal of Slavic Linguistics, 4, 274-311.

Kratzer, A. (1998). More structural analogies between tenses and pronouns. In D. Strolovitch \& A. Lawson (Eds.), Proceedings of SALT VIII (pp. 92-110). Ithaca, N.Y.: CLC Publications.

Lambova, M. (2002). Is head movement syntactic: Evidence from Bulgarian. MIT Working Papers in Linguistics, 43, 91-104.

Laughren, M. (1989). The configurationality parameter and Warlpiri. In L. K Maracz \& P. Muysken (Eds.), Configurationality: The typology of asymmetries (pp. 319-353). Dordrecht: Foris.

Laughren, M. (2002). Syntactic constraints in a 'free word order language. In M. Amberber \& P. Collins (Eds.), Language universals and variation (pp. 83-130). Ablex Publishing Corp.

Legate, J. A. (1996). Irish non-verbal predication: A reanalysis. Toronto Working Papers in Linguistics, 15:1, 55-69.

Legate, J. A. (2002). Warlpiri: Theoretical implications. MIT dissertation. Distributed by MITWPL.

Legate, J. A. (2003a). The configurational structure of a nonconfigurational language. Linguistic Variation Yearbook Vol. 1 2001, 61-104.

Legate, J. A. (2003b). The morpho-semantics of Warlpiri counterfactual conditionals. Linguistic Inquiry, 34.1, 155-162.

Legate, J. A. (2005). Split absolutive. In A. Johns, D. Massam, \& J. Ndayiragije (Eds.), Ergativity (pp. 143-171). Dordrecht: Kluwer.

Legate, J. A. (in preparation). Warlpiri Preverbs. Cornell University ms.

Legendre, G. (1998). Second position clitics in a V2 language: Conflict resolution in Macedonian. In J. Austin \& A. Lawson (Eds.), Proceedings of the 1997 ESCOL meeting (pp. 139-149). CLC Publications, Cornell University.

Legendre, G. (1999). Morphological and prosodic alignment at work: The case of south-slavic clitics. In S. J. Blake, E.-S. Kim, \& K. N. Shahin (Eds.), Proceedings of WCCFL XVII. CSLI Publications (pp. 436-450). Stanford University.

Legendre, G. (2000a). Optimal Romanian clitics: A cross-linguistic perspective. In V. Motapanyane (Ed.), Comparative studies in Romanian syntax (Vol. 58, pp. 227-264). Oxford: Elsevier, North Holland Linguistic Series.

Legendre, G. (2000b). Morphological and prosodic alignment of bulgarian clitics. In J. Dekkers, F. van der Leeuw, \& J. van de Weijer (Eds.), Optimality theory: Syntax, phonology, and acquisition (pp. 423-462). Oxford University Press. 
Legendre, G. (2000c). Positioning Romanian verbal clitics at PF: An optimality-theoretic analysis. In B. Gerlach \& J. Grijzenhout (Eds.), Clitics from different perspectives (pp. 219-254). Johns Benjamins.

Lema, J., \& Rivero, M.-L. (1990). Long head movement: ECP vs. HMC. In Proceedings of NELS 20 (pp. 333-347). GLSA, University of Massachusetts, Amherst.

Maling, J. (1990). Inversion in embedded clauses in modern icelandic. In J. Maling \& A. Zaenen (Eds.), Syntax and semantics 24: modern icelandic syntax (pp. 71-91). San Diego: Academic Press.

Marantz, A. (1984). On the nature of grammatical relations. Cambridge, MA: MIT Press.

Marantz, A. (1988). Clitics, morphological merger, and the mapping to phonological structure. In M. Hammond \& M. Noonan (Eds.), Theoretical morphology (pp. 253-270). Academic Press.

Marantz, A. (1995). A late note on late insertion. In K. Young-Sun, et al. (Eds.), Explorations in generative grammar (pp. 396-413). Seoul: Hankuk Publishing Co.

Marantz, A. (2001). Words. MIT ms.

Massam, D., \& Smallwood, C. (1997). Essential features of predication in English and Niuean. In Proceedings of NELS 27. Amherst: GLSA.

Matthewson, L. (2002). An underspecified tense in Stát'imcets. Paper presented at WECOL, University of British Columbia, Vancouver.

McConvell, P. (1996). The functions of split-Wackernagel clitic systems: Pronominal clitics in the Ngumpin languages. In A. Halpern \& A. Zwicky (Eds.), Approaching second (pp. 299-331). Stanford: CSLI.

Nash, D. (1982). Warlpiri preverbs and verb roots. In S. Swartz (Ed.), Papers in Warlpiri grammar: In memory of Lothar Jagst work papers of SIL-AAB, series A (Vol. 6, pp. 165-216). Berrimah, N.T.: SIL-AAB.

Nash, D. (1986). Topics in Warlpiri grammar. New York, London: Garland.

Pensalfini, R. (2000). Suffix coherence and stress in Australian languages. In J. Henderson (Ed.), Proceedings of the 1999 conference of the Australian linguistic society.

Pentland, C. (2004). Stress in Warlpiri: Stress domains and word-level prosody. Masters thesis, The University of Queensland.

Pentland, C., \& Laughren, M. (2004). Distinguishing prosodic word and phonological word in Warlpiri: Prosodic constituency in morphologically complex words. Paper presented at the Australian linguistic society annual conference 2004, University of Sydney.

Pesetsky, D. (1997). Optimality theory and syntax: Movement and pronunciation. In D. Archangeli \& D. T. Langendoen (Eds.), Optimality theory: An overview (pp. 134-170). Oxford: Blackwell.

Platzack, C. (1987). The Scandinavian languages and the null-subject parameter. Natural Language and Linguistic Theory, 5, 377-401.

Platzack, C. (1988). The emergence of a word order difference in Scandinavian subordinate clauses. McGill Working Papers in Linguistics: Special Issue on Comparative German Synatax, 215-238

Poole, G., \& Burton-Roberts, N. (2004). MLC violations: Implications for the syntax/phonology interface. In A. Stepanov, G. Fanselow, \& R. Vogel (Eds.), Minimality effects in syntax (pp. 327-366). New York: de Gruyter.

Progovac, L. (1996). Clitics in Serbian/Croatian: Comp as the second position. In A. Halpern \& A. Zwicky (Eds.), Approaching second (pp. 411-428). Stanford: CLSI.

Ramchand, G. (2004). Distinguishing event structure from temporal structure. Paper presented at GLOW 27, Aristotle University of Thessaloniki, Greece.

Rivero, M.-L. (1991). Long head movement and negation: Serbo-Croatian vs Slovak and Czech. The Linguistic Review, 8, 319-351.

Rivero, M.-L. (1994). Clause structure and V-movement in the languages of the Balkans. Natural Language and Linguistic Theory, 12, 63-120.

Rivero, M.-L. (1998). Verb movement and economy: Last resort. In M. Dimitrova-Vulchanova \& L. Hellan (Eds.), Topics in south slavic syntax and semantics (pp. 1-23). Amsterdam: Benjamins.

Rivero, M.-L. (2000). Finiteness and second position in long head movement languages: Breton and slavic. In R. Borsley (Ed.), Syntax and semantics 32 (pp. 295-321). New York: Academic Press. 
Rivero, M.-L. (2003). Comparative balkan syntax. Cambridge: Oxford University Press.

Rizzi, L. (1990). Relativized minimality. Cambridge, MA: MIT Press.

Rizzi, L. (1997). The fine structure of the left periphery. In L. Haegeman (Ed.), Elements of grammar (pp. 281-337). Dordrecht: Kluwer.

Roberts, I. (1991). Excorporation and minimality. Linguistic Inquiry, 22, 209-218.

Roberts, I. (1993). Verbs and diachronic syntax. Dordrecht: Kluwer.

Rögnvaldsson, E., \& Thráinsson, H. (1990). On icelandic word order once more. In J. Maling \& A. Zaenen (Eds.), Syntax and semantics 24: Modern icelandic syntax (pp. 3-40). San Diego: Academic Press.

Schütze, C. (1994). Serbo-Croatian second position clitic placement and the phonology-syntax interface. In A. Carnie \& H. Harley (Eds.), MITWPL 21: Papers on phonology and morphology (pp. 373-473).

Selkirk, E. (1986). On derived domains in sentence phonology. Phonology, 3, 371-405.

Selkirk, E. (1995). The prosodic structure of function words. In J. Beckman, L. W. Dickey, \& S. Urbanczyk (Eds.), Papers in optimality theory (pp. 439-470). Amherst: Dept. of Linguistics, University of Massachusetts.

Simpson, J. (1991). Warlpiri Morpho-Syntax. A lexicalist approach. Dordrecht: Kluwer Academic Publishers.

Smith, C. (1991). The paramter of aspect. Kluwer: Dordrecht.

Speas, M. J. (1990). The structure of Warlpiri. In Phrase structure in natural language. Studies on natural language and linguistic theory 21 (pp. 159-172). Dordrecht: Kluwer Academic Publishers.

Stjepanović, S. (1998). On the placement of Serbo-Croatian clitics: Evidence from VP ellipsis. Linguistic Inquiry, 29, 527-237.

Svenonius, P. (2004). Slavic prefixes inside and outside VP. Nordlyd, 32.2, 205-253.

Tomić, O. M. (1996). The Balkan Slavic clausal clitics. Natural Language and Linguistic Theory, $14,811-872$.

Verkuyl, H. J. (1989). Aspectual classes and aspectual composition. Linguistics and Philosophy, 12, 39-94.

Warlpiri Dictionary Project (1993). Warlpiri dictionary. Ongoing work with numerous contributers. Machine-readable data files, deposited at ASEDA, AIATSIS.

Wilder, C., \& Ćavar, D. (1994a). Long head movement? Verb movement and cliticization in Croatian. Lingua, 93, 1-58.

Wilder, C., \& Ćavar, D. (1994b). Word order variation, verb movement, and economy principles. Studia Linguistica, 48, 46-86.

Zagona, K. (2004) Tense construal in complement clauses: Verbs of communication and the double access reading. In J. Guron \& J. Lecarme (Eds.), The syntax of time (pp. 637-654). Cambridge, Mass.: MIT Press.

Zec, D. (1988). Sonority constraints on prosodic structure. Ph.D. thesis, Stanford University. 